\title{
Variability in contrast agent uptake by different but similar stem cell types
}

This article was published in the following Dove Press journal:

International Journal of Nanomedicine

28 November 2013

Number of times this article has been viewed

\author{
Ashwini Ketkar-Atrel \\ Tom Struys ${ }^{1,2}$ \\ Stefaan J Soenen ${ }^{3}$ \\ Ivo Lambrichts ${ }^{2}$ \\ Catherine MVerfaillie ${ }^{4}$ \\ Marcel De Cuyper ${ }^{5}$ \\ Uwe Himmelreich' \\ 'Biomedical MRI/MoSAIC, \\ Department of Imaging and Pathology, \\ Biomedical Sciences Group, \\ Katholieke Universiteit Leuven, \\ Leuven, Belgium; ' ${ }^{2}$ Lab of Histology, \\ Biomedical Research Institute, Hasselt \\ University, Campus Diepenbeek, \\ Agoralaan, Diepenbeek, Belgium; \\ ${ }^{3}$ Lab for General Biochemistry \\ and Physical Pharmacy, Faculty of \\ Pharmacy, Ghent University, Ghent, \\ Belgium; ${ }^{4}$ Interdepartmental Stem \\ Cell Institute, O\&N IV, Katholieke \\ Universiteit Leuven, Leuven, Belgium \\ ${ }^{5}$ Laboratory of BioNanoColloids, \\ Interdisciplinary Research Centre, \\ Katholieke Universiteit Leuven, \\ Kortrijk, Belgium
}

Correspondence: Uwe Himmelreich Biomedical MRI Unit/MoSAIC, Katholieke Universiteit Leuven, O\&NI, BUS 505, Herestraat 49, B-3000 Leuven, Belgium $\mathrm{Tel}+3216330925$

Fax +32 I6 33090 I

Email uwe.himmelreich@med.kuleuven.be

\begin{abstract}
The need to track and evaluate the fate of transplanted cells is an important issue in regenerative medicine. In order to accomplish this, pre-labelling cells with magnetic resonance imaging (MRI) contrast agents is a well-established method. Uptake of MRI contrast agents by non-phagocytic stem cells, and factors such as cell homeostasis or the adverse effects of contrast agents on cell biology have been extensively studied, but in the context of nanoparticle (NP)-specific parameters. Here, we have studied three different types of NPs (Endorem ${ }^{\circledR}$, magnetoliposomes [MLs], and citrate coated C-200) to label relatively larger, mesenchymal stem cells (MSCs) and, much smaller yet faster proliferating, multipotent adult progenitor cells (MAPCs). Both cell types are similar, as they are isolated from bone marrow and have substantial regenerative potential, which make them interesting candidates for comparative experiments. Using NPs with different surface coatings and sizes, we found that differences in the proliferative and morphological characteristics of the cells used in the study are mainly responsible for the fate of endocytosed iron, intracellular iron concentration, and cytotoxic responses. The quantitative analysis, using high-resolution electron microscopy images, demonstrated a strong relationship between cell volume/surface, uptake, and cytotoxicity. Interestingly, uptake and toxicity trends are reversed if intracellular concentrations, and not amounts, are considered. This indicates that more attention should be paid to cellular parameters such as cell size and proliferation rate in comparative cell-labeling studies.
\end{abstract}

Keywords: cell labeling, MR contrast agents, transmission electron microscopy, mesenchymal stem cells, multipotent adult progenitor cells, magnetic resonance imaging, nanoparticles, iron oxide

\section{Introduction}

Mesenchymal stem cells (MSCs) and multipotent adult progenitor cells (MAPCs), both isolated from bone marrow, are two stem cell types that are currently under extensive investigation. ${ }^{1-5}$ Due to their origin, bone marrow-derived stem cells are less debated from an ethical point of view than embryonic stem cells (ESCs). MSCs can differentiate into a number of mesenchymal phenotypes, including adipocytes, osteocytes, chondrocytes, and myocytes. ${ }^{6-8}$ MSCs can also inhibit the function of T-cells, B-cells, and dendritic cells, and are therefore being tested clinically in immune disorders such as graft versus host disease (GVHD) and Crohn's disease., ${ }^{9,10}$ MAPCs were first isolated by Jiang et $\mathrm{al}^{11}$ in 2002 and have the ability to differentiate into smooth muscle cells, osteocytes, functional hepatocyte-like cells, and into a neuroectodermal lineage. ${ }^{12}$ Recent work has indicated that rat extra-embryonic endodermal precursor cells (rXENP), rat hypoblast stem cells (rHypoSCs), and rat 
MAPCs (rMAPCs) have highly similar gene expression profiles and developmental potential. ${ }^{13}$ Thus, the HypoSC/ XENP/MAPC phenotype provides a cell model for studying stem cell plasticity, reprogramming, transplantation tolerance, and others, which is crucial for mechanistic studies in regenerative medicine. ${ }^{13,14}$

When considering therapeutic applications of these cells in humans, it is necessary to determine the fate and biodistribution of the stem cells in vivo, without the need for invasive validation by post mortem histology. Thus, the development of sensitive, non-invasive imaging techniques should provide knowledge about the poorly understood mechanisms of the location, migration, and fate of stem cells post-implantation at different time points. ${ }^{15,16}$ Magnetic resonance imaging (MRI) is one of the most attractive non-invasive imaging modalities due to its very high resolution and soft tissue contrast, which are requirements for stem cell tracking in different disease models..$^{15,17-20}$ However, the sensitivity of MRI is limited when compared with other imaging modalities such as X-ray computed tomography (CT), positron emission tomography (PET) and optical imaging. ${ }^{21-23}$ In order to detect cells by MRI, it is necessary to pre-label them with MR-visible contrast agents. The majority of studies have used iron oxide-based nanoparticles (NPs) due to their relatively high sensitivity and their acceptable biocompatibility. ${ }^{15,17,18,24,25,26}$

Several studies have evaluated potential toxic or adverse effects of intracellular iron oxide in cells, where the major focus has been the comparison of different NP-related properties (size, coating, and concentrations). ${ }^{25,27}$ Furthermore, in studies where material-related properties have been the subject of scrutiny, cell-related properties have rarely been addressed. Here, we chose two similar but morphologically distinct stem cell types (MSCs and MAPCs) because of differences in their proliferative capacities (MSCs being a model for slow proliferation, and MAPCs being a model for highly proliferative cells) and average cell sizes (MSCs: 30-50 $\mu \mathrm{m}$ and MAPCs 9-14 $\mu \mathrm{m}$ diameter). Using these cells, we studied the fate of three different types of particles with different sizes and surface charges, namely Endorem ${ }^{\circledR}$ (Guerbet, Roissy, France) (dextran-coated), magnetoliposomes (MLs, phospholipid-coated), and C-200 (citrate coated), to validate uptake efficiency, their intracellular distribution, and potential toxicity. Using ultrastructural analysis, we focused on evaluating the intracellular iron content and the fate of NPs after endocytosis. Thereby, we also assessed the relationship between available cell volume/surface area and possible adverse reactions by the cells.

\section{Materials and methods Cell lines}

All experiments were performed using MAPCs and MSCs. Isolation of MAPCs and MSCs has been described elsewhere. ${ }^{11,28-30}$ Both cell types were acquired from the Stem Cell Institute Leuven (Katholieke Universiteit, Leuven, Belgium). MAPCs were grown in 60\% low-glucose Dulbecco's Modified Eagle's Medium (Gibco ${ }^{\circledR}$, Ghent, Belgium), 40\% MCDB-201, insulin-transferrin-selenium (formulation contains $1.0 \mathrm{mg} / \mathrm{mL}$ recombinant human insulin, $0.55 \mathrm{mg} / \mathrm{mL}$ human transferrin, and $0.5 \mu \mathrm{g} / \mathrm{mL}$ sodium selenite), linoleic acid bovine serum albumin $(100 \mathrm{mg} / \mathrm{mL}$ bovine serum albumin), $10^{-9} \mathrm{M}$ dexamethasone, $10^{-4} \mathrm{M}$ ascorbic acid 3-phosphate, $10 \mathrm{ng} / \mathrm{mL}$ mouse epidermal growth factor (all components were from Sigma, Bornem, Belgium). Penicillin (100 units) and $100 \mu \mathrm{g}$ of streptomycin (Cellgro, Manassas, VA, USA), 2\% fetal bovine serum (HyClone, Aalst, Belgium), $10 \mathrm{ng} / \mathrm{mL}$ human plateletderived growth factor (R\&D Systems, Minneapolis, MN, USA), 1,000 units/mL mouse leukemia inhibitory factor (Chemicon, Billerica, MA, USA) were added to avoid differentiation. In addition, 0.7\% $\beta$-mercaptoethanol (Gibco) was added fresh. The medium was sterilized using a $0.22 \mu \mathrm{m}$ filter (Millipore, Overijse, Belgium) and kept at $4^{\circ} \mathrm{C}$ for up to 2 weeks at a $\mathrm{pH}$ of 7.2. Cells were split every $36-48$ hours at $80 \%$ confluence. MSCs were maintained in medium containing Iscove's Modified Dulbecco's Medium (Gibco) supplemented with 10\% fetal bovine serum (HyClone), 10\% horse serum (Biochrom, Berlin, Germany), 1\% L-glutamine (Gibco), and 100 units of penicillin and $100 \mu \mathrm{g}$ of streptomycin (Cellgro). Cells were split every 60-72 hours at $70 \%-80 \%$ confluence.

\section{Nanoparticles}

Labeling experiments were performed using 1) the small superparamagnetic, iron oxide-based NPs Endorem ${ }^{\circledR}$ (Guerbet, Roissy, France), 2) the very small iron oxide particles (VSOPs) C-200 (Ferropharm GmbH, Teltow, Germany), and 3) in-house synthesized superparamagnetic cationic MLs as described in De Cuyper and Joniau. ${ }^{31}$ In short, cationic MLs were made starting with lauric acid-coated $\mathrm{Fe}_{3} \mathrm{O}_{4}$ NPs $(14.1 \pm 0.4 \mathrm{~nm})$ in a two-step process as described in De Cuyper and Joniau ${ }^{31}$ and Soenen et al. ${ }^{32}$ High-gradient magnetophoresis was employed to purify the magnetic 
particles, which were coated with a lipid bi-layer consisting of a neutral dimyristoylphosphatidylcholine (Avanti Polar Lipids, Alabaster, AL, USA) matrix (96.7\%) and further bestowed with $3.3 \%$ cationic distearoyl-trimethylammonium propane (Avanti Polar Lipids). A detailed description of the particles and their labeling concentrations can be found in Table 1. Poly-L-lysine (PLL, 388 kDa, Sigma) was used as transfection agent whenever it was necessary to improve the cellular uptake of NPs as described previously. ${ }^{33}$

\section{Cell labeling}

From initial optimization experiments (this study and Crabbe et $\mathrm{al}^{33}$ ), we used Endorem ${ }^{\circledR}$ with and without PLL with a labeling concentration of $0-400 \mu \mathrm{g} \mathrm{Fe} / \mathrm{mL}$ medium. Different iron concentrations were used for labeling MAPCs and MSCs with VSOPs and MLs as indicated in Table 1. For all labeling experiments, the initial seeding density for both cell types was adapted from previously published studies where MAPCs were seeded at $5 \times 10^{2}$ cells $/ \mathrm{cm}^{2}$ and MSCs at a higher cell density of $40 \times 10^{2}$ cells $/ \mathrm{cm}^{2}{ }^{28,30}$ The number of cells used for the various experiments is mentioned under the respective sections. Coincubation with NPs was optimized according to Crabbe et al for 4-48 hours and finally performed for 24 hours. $^{33}$

\section{Cellular iron content}

Cells were seeded at an initial seeding density (MAPCs: $5 \times 10^{2}$ cells $/ \mathrm{cm}^{2}$, MSCs: $40 \times 10^{2}$ cells $/ \mathrm{cm}^{2}$ ) and labeled with different labeling concentrations for 24 hours. After co-incubation, cells were washed three times with phosphate buffered saline (PBS) and incubated in iron-free medium for 4 hours. Afterwards, cells were trypsinized and counted. Pellets of $10^{5}$ cells were lysed with concentrated $3.7 \% \mathrm{HCl}$ (Vel labs, Leuven, Belgium). Samples were further homogenized with distilled water. For quality control purposes, standard solutions of $0.1,0.5$, and $1.0 \mathrm{ppm}$ were measured before the first sample and after every tenth sample. Quantification of the iron content in the cells was performed with inductively coupled plasma optical emission spectrometry (ICP-OES, Varian, 720ES, Santa Clara, CA, USA).

\section{Cell proliferation and metabolic activity}

To evaluate the effect of labeling on the proliferative capacity and viability of the cells, a population doubling time and a 3-(4,5-Dimethylthiazol-2-yl)-2,5-diphenyltetrazolium bromide (MTT) assay was performed. Population doubling times were assessed by total cell count using an automatic cell counter (Chemometec, Lillerod, Denmark). Population doubling times were determined using $\mathrm{t} \times \ln (2) / \ln (\mathrm{A} / \mathrm{A} 0)$, where $t$ is the time between two cell counts, $A$ is the number of cells at the end of the incubation, and $\mathrm{A} 0$ is the initial number of cells. The population doubling time of the labeled cell population was followed for 6 days for MAPCs and 9 days for MSCs post-labeling.

Cell viability was assessed post-labeling by the MTT assay as originally described by Mosmann. ${ }^{34}$ MAPCs and MSCs were plated at the initial seeding density and incubated with different NPs using the above-mentioned conditions. After labeling, all samples were washed three times with PBS (without $\mathrm{Mg}^{2+}$ and $\mathrm{Ca}^{2+}$ ) and further incubated for 4 hours in iron-free medium. Cells were detached using 0.05\% trypsin-ethylenediaminetetraacetic acid (EDTA; Gibco) and transferred into a 96-well plate at $1-2 \times 10^{4}$ cells/well for MAPCs and 5-10 $\times 10^{4}$ cells/well for MSCs. These cells were allowed to adhere and were incubated with the MTT solution $(0.5 \mathrm{mg} / \mathrm{mL}$ in medium; Sigma-Aldrich, Bornem, Belgium) for 2 (MAPCs) and 4 (MSCs) hours at $37^{\circ} \mathrm{C}$ and $5 \% \mathrm{CO}_{2}$. The medium was then removed and $100 \mu \mathrm{L}$ lysis buffer $(1 \%$ Triton $\mathrm{X}-100$ in isopropanol) was added to each well and extensively mixed. The optical density was then measured at $570 \mathrm{~nm}$ using an absorbance plate reader (Wallac, Victor2, Perkin Elmer, Zaventem, Belgium). The viability of cells was represented as $\%$ viability normalized to non-labeled samples (100\%).

\section{Confirmation of NP uptake using transmission electron microscopy (TEM) and Prussian blue staining}

To confirm uptake of NPs and their intracellular distribution, TEM was performed. For TEM analysis, cells were plated at

Table I Nanoparticles used for different cell labeling conditions

\begin{tabular}{llllll}
\hline Particles & $\begin{array}{l}\text { Types of } \\
\text { particles }\end{array}$ & $\begin{array}{l}\text { Hydrodynamic } \\
\text { size of particles }\end{array}$ & $\begin{array}{l}\text { Coating } \\
\text { material }\end{array}$ & $\begin{array}{l}\text { MAPCs labeling concentration } \\
(\mu \mathrm{g} \mathrm{Fe} / \mathbf{m L} \text { in medium })\end{array}$ & $\begin{array}{l}\text { MSCs labeling concentration } \\
(\mu \mathrm{g} \mathrm{Fe} / \mathbf{m L} \text { in } \mathbf{m e d i u m})\end{array}$ \\
\hline Endorem $^{\circledast}$ & SPIOs & $80-120 \mathrm{~nm}$ & Dextran & $50-400$ & $50-400$ \\
MLs & USPIOs & $40 \mathrm{~nm}$ & Lipid & $20-50$ & $50-400$ \\
C-200 & VSOPs & $8-10 \mathrm{~nm}$ & Citrate & $50-200$ & $50-200$ \\
\hline
\end{tabular}

Abbreviations: MLs, magnetoliposomes; MSCs, mesenchymal stem cells; SPIOs, superparamagnetic iron oxides; USPIOs, ultrasmall superparamagnetic iron oxides; VSOPs, very small iron oxide particles; MAPCs, multipotent adult progenitor cells. 
their initial seeding density (MAPCs: $5 \times 10^{2}$ cells $/ \mathrm{cm}^{2}$, MSCs: $40 \times 10^{2}$ cells $/ \mathrm{cm}^{2}$ ) and labeled with NPs under different labeling conditions for 24 hours. After labeling with NPs, cells were washed and incubated in iron-free medium for 4 hours. Cells were detached using 0.05\% trypsin-EDTA (Gibco) and transferred to plastic Nunc Thermanox ${ }^{\circledR}$ (Thermo Scientific, Rochester, NY, USA) coverslips at a density of 2.5-5 $\times 10^{4}$ cells/ $\mathrm{cm}^{2}$. Immediately after adhering on the cover slip surface, cells were fixed with $2 \%$ glutaraldehyde (Laborimpex NV, Brussels, Belgium) in 0.05 M sodium cacodylate buffer (Aurion, Wageningen, The Netherlands) at $\mathrm{pH}=7.3$ and a temperature of $4^{\circ} \mathrm{C}$. Samples were further prepared as described in Struys et al. ${ }^{35}$ Briefly, following embedding in epoxy resin (araldite; Aurion, Wageningen, The Netherlands), samples were cut in sections of 40-60 nm, using a Leica EM UC6 microtome (Leica, Groot Bijgaarden, Belgium). They were then transferred to 50 mesh copper grids (Aurion, Wageningen, The Netherlands) coated with $0.7 \%$ formvar. Samples were automatically stained with $0.5 \%$ uranyl acetate and stabilized in a solution of lead citrate (both from Laurylab, Saint-Fons, France) using a Leica EM AC20 (Leica). ${ }^{35}$ TEM analysis was performed with a Philips EM208 S electron microscope (Philips, Eindhoven, The Netherlands) provided with a Morada Soft Imaging System camera to acquire high-resolution TEM images. The images were processed digitally with the iTEMFEI software (Olympus SIS, Münster, Germany).

For Prussian blue staining, labeled cells were fixed in 4\% paraformaldehyde (Sigma) for 15 minutes at room temperature. Solutions of $2 \% \mathrm{HCl}$ (Vel Labs, Leuven, Belgium) and $2 \%$ potassium ferrocyanide (Sigma) were mixed just before incubation with cells for 15 minutes. Eosin (Sigma) was used for counter staining.

\section{Quantification of NPs per cell volume}

The relationship between available cell volume and the intracellular iron concentrations was determined based on the TEM (volume) and ICP-OES (iron content) data. Those data were then set in relation to the cell viability experiments. For quantification purposes, we assume that the distribution of particles in the endosomes is homogenous, and that cells and NPs are spherical in shape. The dimensions of the cells and nuclei $(\mathrm{n}=25)$ were determined experimentally from TEM data. The cell cytoplasm volume was calculated by substracting the volume of the nucleus from total cell volume.

\section{Magnetic resonance imaging}

Labeled cells were scanned by MRI in order to assess the detectability threshold for different amounts of cells and for different NP concentrations. To prepare MR phantoms for imaging, labeled cells were washed with PBS. After trypsinizing and centrifugation (1,500 rpm), cell suspensions were made using the respective cell culture medium. After cell counting, $10^{5}$ cells were again pelleted and resuspended in $100 \mu \mathrm{L}$ of PBS. These cell suspensions $(1,000$ cells $/ \mu \mathrm{L})$ were mixed with $1.5 \%$ agarose (Sigma) in a $1: 1$ ratio and transferred into $250 \mu \mathrm{L}$ microcentrifuge tubes one-third prefilled with solidified agarose. All microcentrifuge tubes (now containing 500 cells $/ \mu \mathrm{L}$ ) were assembled in a pre-made matrix made of $1.5 \%$ agarose. ${ }^{35}$ Upon solidifying, the agarose gel phantoms were scanned using a $9.4 \mathrm{~T}$ Bruker Biospec small animal MR scanner (Bruker Biospin, Ettlingen, Germany; horizontal bore $20 \mathrm{~cm}$ ) equipped with actively shielded gradients $\left(600 \mathrm{mT} \mathrm{m}^{-1}\right)$. A quadrature radio-frequency resonator (transmit/receive; inner diameter $7 \mathrm{~cm}$, Bruker Biospin) was used for data acquisition. Two-dimensional multi-slice-multi-echo (MSME) scans were acquired for the calculation of T2 values (TR [repetition time] $=3,000 \mathrm{~ms}$ and $16 \mathrm{TE}$ [echo time] increments of $8 \mathrm{~ms}, 256 \times 256$ matrix with $234 \times 234 \mu \mathrm{m}$ in plane resolution). Three-dimensional, high-resolution T $2 *$-weighted MR images were acquired using a gradient echo sequence (FLASH, TR $=200 \mathrm{~ms}, \mathrm{TE}=15 \mathrm{~ms}$ ). The field of view was $6.0 \times 6.0 \times 2.25 \mathrm{~cm}$, resulting in an isotropic resolution of $234 \mu^{3}$. Images were processed with Paravision 5.0/5.1 (Bruker Biospin, Ettlingen, Germany).

\section{Label dilution}

To validate cell detection after further proliferation, the dilution of the NPs was followed for MAPCs and MSCs for 1 week post-labeling using ICP-OES, three-dimensional $\mathrm{T} 2 *$ weighted high-resolution MR images and TEM (using above-mentioned protocols). Hereby, cells were split regularly and always seeded at their initial seeding density in NP-free medium.

\section{Statistical analysis}

Statistical analysis was performed using Graphpad Prism 5 software (Graphpad, La Jolla, CA, USA). Significant differences between experimental groups were determined using the two-way analysis of variance test with a Tukey post or Bonferroni post-test after normalizing the data. Plotted data were represented as mean \pm standard error (SE). Whereas iron concentration values (in $\mathrm{fg} / \mu \mathrm{m}^{3}$ ) are indicated as mean \pm standard deviation (SD) throughout the text. $P$-values $\leq 0.05$ were considered statistically significant at the $5 \%$ significance level. 


\section{Results}

\section{Cellular iron quantification}

Iron uptake was quantified using ICP-OES. Figure $1 \mathrm{~A}$ and B show uptake of various NPs by MSCs and MAPCs for all concentrations of NPs. Conjugation of PLL to Endorem ${ }^{8}$ was performed in order to evaluate whether intracellular iron concentrations can be further elevated at lower concentrations in the culture medium. Addition of PLL to Endorem ${ }^{\circledR}$ increased the intracellular iron content by four-fold in MAPCs, whereas MSCs showed a six-fold increase at lower incubation concentrations of $50 \mu \mathrm{g} \mathrm{Fe} / \mathrm{mL}$. Very low amounts of iron were found in MSCs compared with MAPCs when labeled with $50 \mu \mathrm{g} \mathrm{Fe} / \mathrm{mL}$ of medium using cationic MLs and VSOPs. Increase of iron in the medium for labeling with cationic MLs and VSOPs resulted in increased uptake until toxic effects were seen. This was not the case for labeling with Endorem ${ }^{\circledR} \pm$ PLL. Uptake saturation was seen when MAPCs were labeled with Endorem ${ }^{\circledR}+$ PLL (for 50-400 $\mu \mathrm{g}$ $\mathrm{Fe} / \mathrm{mL}$ ), corresponding to intracellular amounts of iron up to $18 \mathrm{pg}$ /cell. Utilization of TEM-based cell volumes (see also Table 2) indicated that MAPCs have a ten times smaller volume than MSCs, which explains the much lower iron concentration $\left(\mathrm{fg} / \mu^{3}\right)$ in MSCs for a similar absolute amount of intracellular iron when compared with MAPCs. Due to this large difference in cell volumes between MSCs and MAPCs, the uptake of iron was also expressed in intracellular concentrations (Figure 1). While the total iron content per cell was, to a large extent, comparable between the two
A

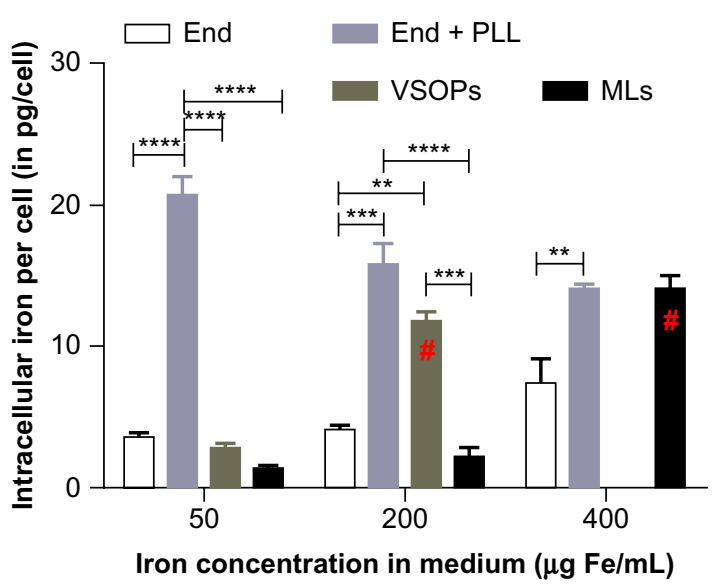

C

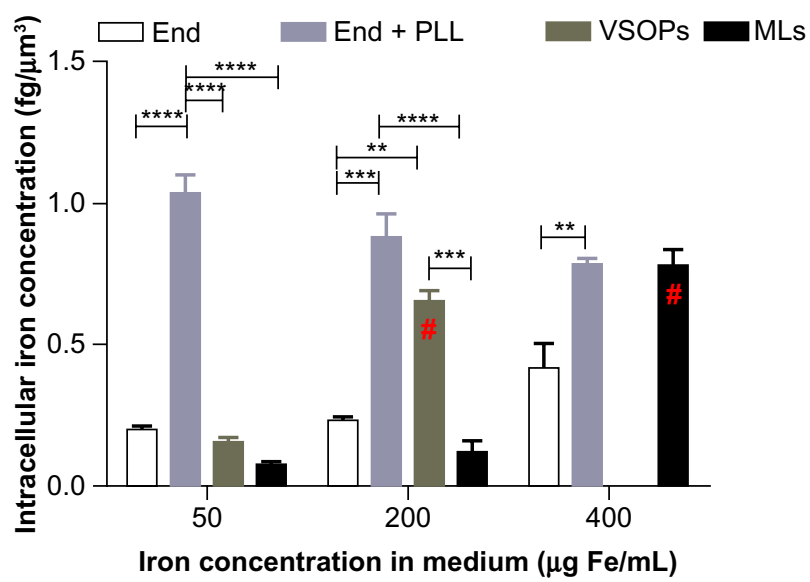

B

MAPCs

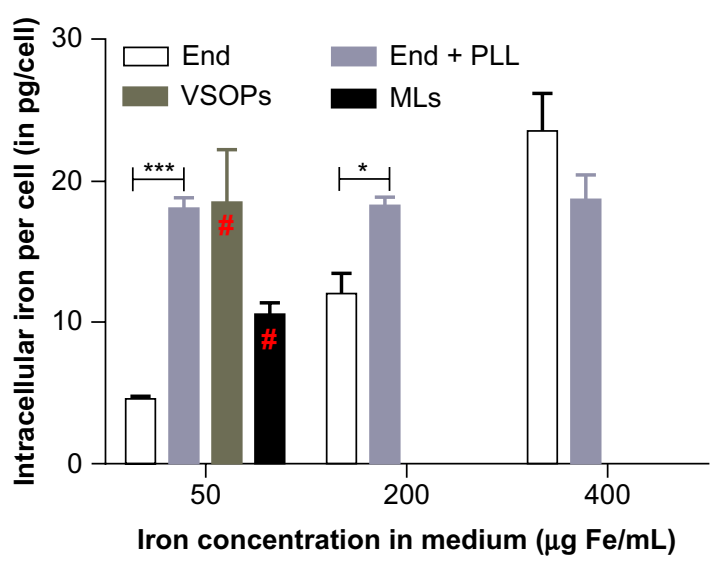

D

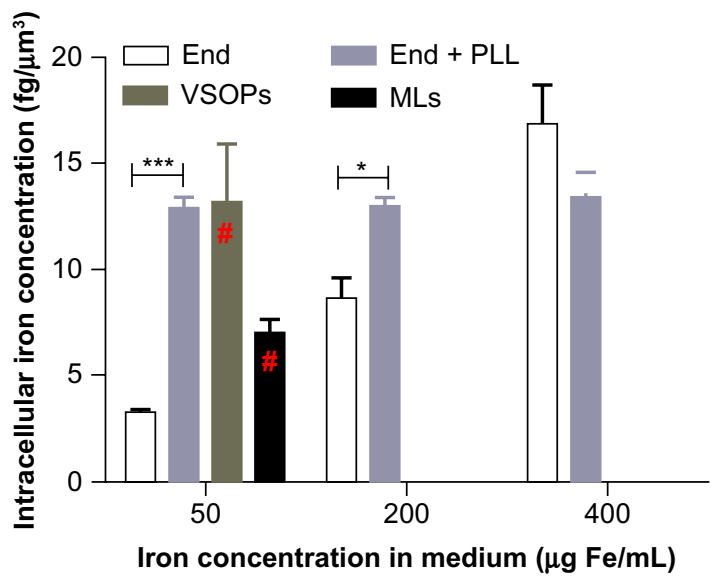

Figure I Quantification of iron uptake and intracellular concentration: (A and B) iron uptake in both types of cells was quantified using ICP-OES for all labeling concentrations (A) MSCs, (B) MAPCs. (C and D) Intracellular iron concentration (iron mass/volume of cytosol) was plotted against labeling conditions for (C) MSCs and (D) MAPCs, indicating that a higher iron concentration was present in MAPCs.

Notes: $* P<0.05 ; * * P<0.01$; $* * * P<0.00$ I; $* * * * P<0.000$ I. "Toxic concentration.

Abbreviations: End, Endorem ${ }^{\circledast}$; ICP-OES, inductively coupled plasma optical emission spectrometry; MAPCs, multipotent adult progenitor cells; MLs, magnetoliposomes; MSCs, mesenchymal stem cells; PLL, poly-L-lysine; VSOPs, very small iron oxide particles. 
Table 2 Calculation of intracellular iron concentration per cell volume

\begin{tabular}{lllllll}
\hline $\begin{array}{l}\text { Labeling condition } \\
(\mu \mathbf{g ~ F e} / \mathbf{m L})\end{array}$ & $\begin{array}{l}\text { Size of } \\
\text { particles }(\mathbf{n m})\end{array}$ & $\begin{array}{l}\text { Iron uptake } \\
(\mathbf{p g} / \mathbf{c e l l})^{*}\end{array}$ & $\begin{array}{l}\text { Volume of } \\
\text { particles }\left(\mu \mathbf{m}^{3}\right)\end{array}$ & $\begin{array}{l}\text { Volume of } \\
\text { cytoplasm }\left(\mu \mathbf{m}^{3}\right)^{\dagger}\end{array}$ & $\begin{array}{l}\text { \% volume } \\
\text { occupied }\end{array}$ & $\begin{array}{l}\text { Iron concentration } \\
\left(\mathbf{f g} / \mu \mathbf{m}^{3}\right)\end{array}$ \\
\hline $\begin{array}{l}\text { MAPCs } \\
\text { MLs (50) }\end{array}$ & 40 & $10.4 \pm 0.9$ & $2.12 \pm 0.9$ & 1,400 & 0.156 & 7.4 \\
$\quad$ VSOP (50) & 10 & $18.4 \pm 3.9$ & $3.76 \pm 3.9$ & 1,400 & 0.276 & 13.1 \\
MSCs & & & & & & \\
MLs (50) & 40 & $1.3 \pm 0.2$ & $0.27 \pm 0.2$ & 18,000 & 0.001 & 0.1 \\
MLs (400) & 40 & $14 \pm 1.0$ & $2.86 \pm 1.0$ & 18,000 & 0.016 & 0.8 \\
VSOPs (50) & 10 & $2.8 \pm 0.4$ & $0.41 \pm 0.4$ & 18,000 & 0.002 & 0.2 \\
VSOPs (200) & 10 & $11.7 \pm 0.8$ & $2.39 \pm 0.8$ & 18,000 & 0.013 & 0.7 \\
\hline
\end{tabular}

Notes: *Mean \pm SE; 'ंvolume of cytoplasm $=($ volume of the cell $)-($ volume of nucleus $)$. Cytoplasm volume calculations are based on TEM.

Abbreviations: MAPCs, multipotent adult progenitor cells; MLs, magnetoliposomes; MSCs, mesenchymal stem cells; SE, standard error; TEM, transmission electron microscopy; VSOPs, very small iron oxide particles.

stem cell lines, an up to ten-fold higher iron concentration $\left(\mathrm{fg} / \mu \mathrm{m}^{3}\right)$ was observed in MAPCs when compared with MSCs (Figure 1C and D).

\section{Effects on cell proliferation and metabolic activity}

The effect of labeling on cell viability and proliferation was assessed by comparing total cell counts and the MTT assay post-labeling. Proliferation was determined using population doubling time (PDT) from total cell counts for both cell types.

MAPCs and MSCs were labeled with NPs at different concentrations as shown in Table 1 . The effect on cell survival was determined 24 hours after adding the respective NPs and is shown in Figure 2 and Figure S1. A significant effect on cell survival was observed in MAPCs after labeling with VSOPs at $50 \mu \mathrm{g} \mathrm{Fe} / \mathrm{mL}$ medium (corresponding to $13.1 \pm 4.7$ $\mathrm{fg} / \mu^{3}$ ) or higher and after labeling with MLs at a concentration above $20 \mu \mathrm{g} \mathrm{Fe} / \mathrm{mL}$ medium (corresponding to $2.8 \pm 2 \mathrm{fg} /$ $\mu \mathrm{m}^{3}$ at $20 \mu \mathrm{g} \mathrm{Fe} / \mathrm{mL}$ medium and $7.4 \pm 0.9 \mathrm{fg} / \mu \mathrm{m}^{3}$ at $50 \mu \mathrm{g}$ $\mathrm{Fe} / \mathrm{mL}$ medium, respectively). Statistically non-significant, minor reductions of MAPC survival after labeling with high concentrations of Endorem ${ }^{\circledR}( \pm$ PLL) were detected. Similar trends were seen for MSC survival compared to MAPCs but only starting at higher iron concentrations in the medium (Figure 2B).

For labeling MAPCs with Endorem ${ }^{\circledR}$, we only noticed a marginal but non-significant increase in the doubling time of cells labeled with the highest concentrations when compared with unlabeled cells (Figure 2C). Similarly, statistically insignificant effects on MSC proliferation were found following exposure to different Endorem ${ }^{\circledR}$ ( \pm PLL) concentrations (Figure 2D). For all further experiments, we focused on non-toxic NP concentrations.

MTT assays were performed after cell labeling with all NP concentration conditions as shown in Table 1.
Figure 2E indicates significant reductions in metabolic rates for MAPCs when labeled with $200 \mu \mathrm{g} \mathrm{Fe} / \mathrm{mL}$ medium or higher amounts of Endorem ${ }^{\circledR}+$ PLL (corresponding to $\left.12.8 \pm 0.5 \mathrm{fg} / \mu \mathrm{m}^{3}\right)$ and VSOPs and MLs $(\geq 50 \mu \mathrm{g} \mathrm{Fe} / \mathrm{mL}$ medium, corresponding to $13.1 \pm 4.7$ and $7.4 \pm 0.9 \mathrm{fg} / \mu \mathrm{m}^{3}$, respectively) compared with non-labeled controls. However, when the labeling concentrations of NPs in the medium were the same, the metabolic activity of MSCs was unaltered. No effect on the metabolic activity was seen for both cell types for concentrations in the medium that were lower than mentioned in Figure 2E. After comparing metabolic data (Figure 2E) and cell survival data (Figure 2F) post-labeling, it was observed that MSCs were generally more tolerant to higher iron concentrations in the medium than were MAPCs.

Although MAPCs seemed to be more susceptible to high iron concentrations in the medium than MSCs, their intracellular iron concentration was, in many cases, much higher than for the much larger MSCs (see Table 2). When adjusted for the intracellular volume, similar or even higher iron concentrations were found to be toxic for MAPCs compared with MSCs (see Table 2, Figures 1, 2E and F, and Figure S1).

\section{NPs internalization}

To assess the ultrastructural properties of cells post-labeling with NPs, and to distinguish between intracellular iron and potentially extracellular membrane-bound iron, labeled cells were studied with TEM (Figures 3 and 4). Figure 3A clearly indicates that particle uptake occurred via endocytosis. The presence of cellular extensions, pseudopodia, was detected surrounding NPs that accumulated along the cell membrane prior to uptake. This also emphasizes the need to incubate cells in iron-free medium before engraftment in vivo so that remaining extracellular iron can be internalized and so label transfer to host cells can be avoided. For MAPCs, labeling with Endorem ${ }^{\circledR}$ resulted in intracellular particle clustering, 
A

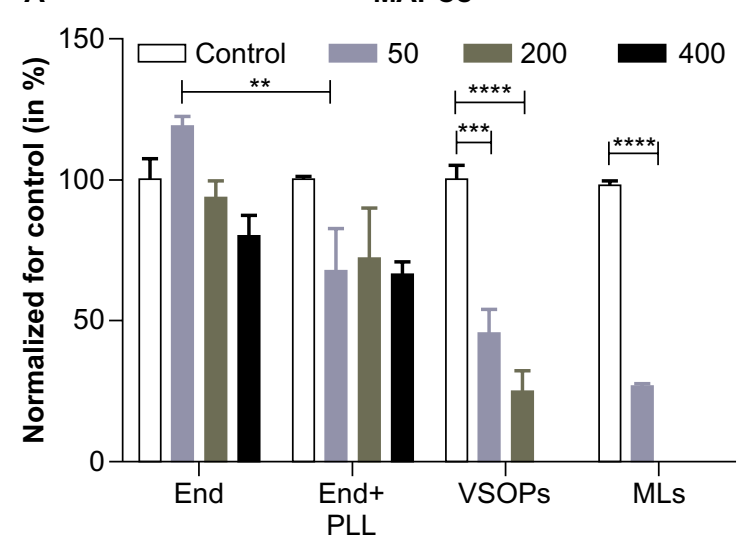

Labeling particles
Total cell count

B

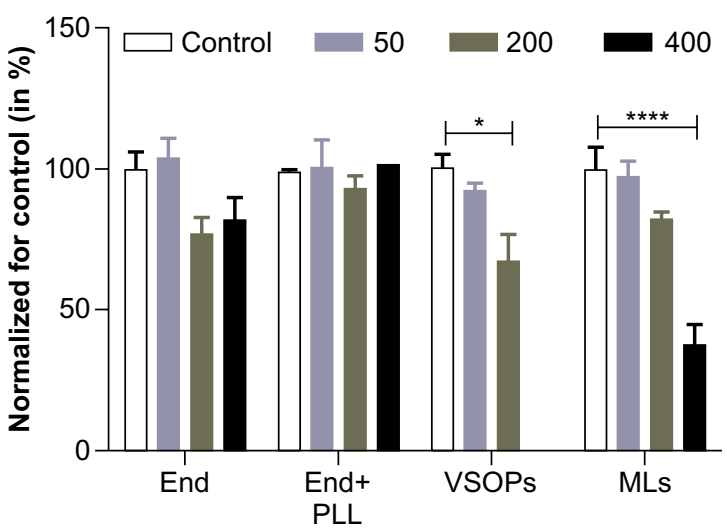

Labeling particles

Endorem ${ }^{\circledast}$ labeling

C

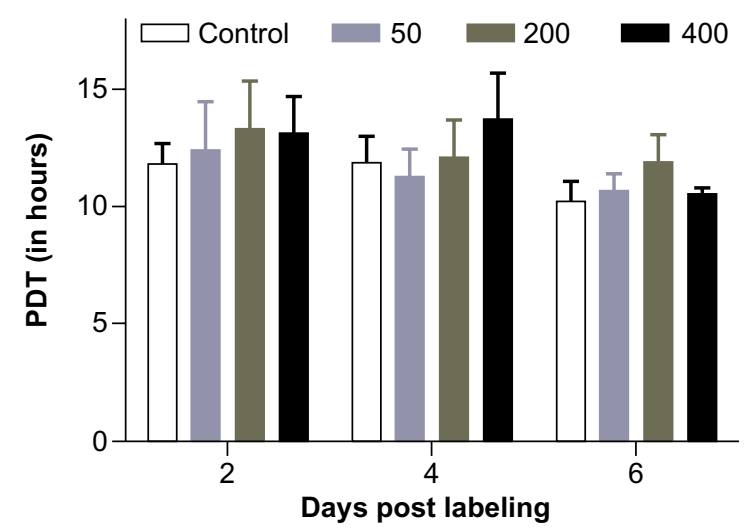

D

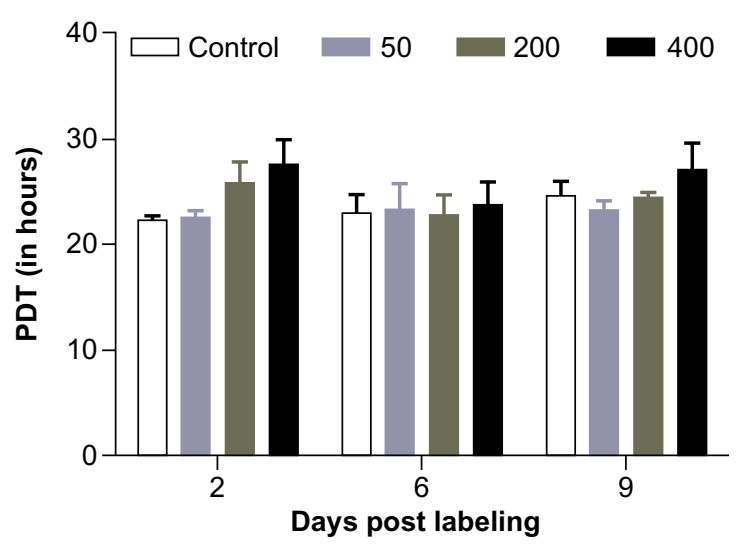

MAPCs vs MSCs

$\mathbf{E}$

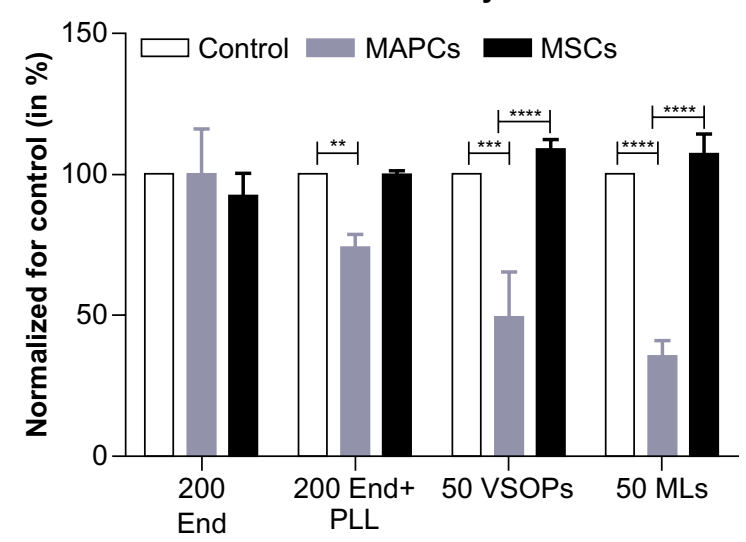

Iron concentration in medium $(\mu \mathrm{g} \mathrm{Fe} / \mathrm{mL})$

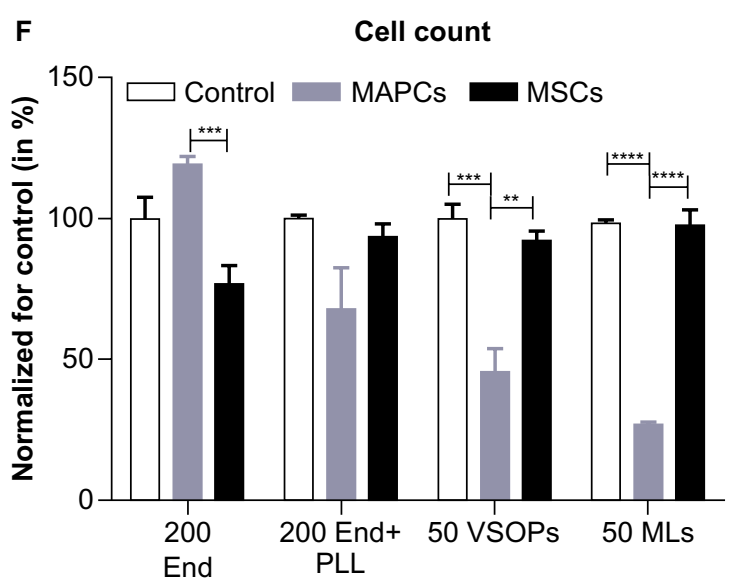

Iron concentration in medium $(\mu \mathrm{g} \mathrm{Fe} / \mathrm{mL})$

Figure 2 Cell proliferation and viability post-labeling: (A) MAPCs, when labeled with Endorem ${ }^{\circledR}( \pm$ PLL), VSOPs, and MLs with different labeling concentrations and counted, showed a significant reduction in the cell count at $50 \mu \mathrm{g} \mathrm{Fe} / \mathrm{mL}$ medium of VSOPs and MLs, whereas a marginal decrease in the cell count was observed for $50 \mu \mathrm{g}$ Fe/mL of Endorem ${ }^{\circledR}+$ PLL. (B) MSCs, when labeled with all NPs, showed significant reductions in the total cell count only at $200 \mu \mathrm{g} F / \mathrm{mL}$ of VSOPs and $400 \mu \mathrm{g}$ Fe/mL of MLs. (C and D) No significant differences were observed with respect to population doubling time (PDT) when MAPCs and MSCs were labeled with Endorem ${ }^{\circledR}$ and followed for 6 and 9 days, respectively. (E) Cell viability (MTT) and (F) cell survival post-labeling was plotted for different labeling conditions.

Notes: $* P<0.05 ; * * P<0.01 ; * * * P<0.001 ; * * * * P<0.0001$.

Abbreviations: End, Endorem ${ }^{\circledR}$; MAPCs, multipotent adult progenitor cells; MLs, magnetoliposomes; MSCs, mesenchymal stem cells; MTT, 3-(4,5-Dimethylthiazol-2-yl)-2,5diphenyltetrazolium bromide; NPs, nanoparticles; PLL, poly-L-lysine; VSOPs, very small iron oxide particles. 


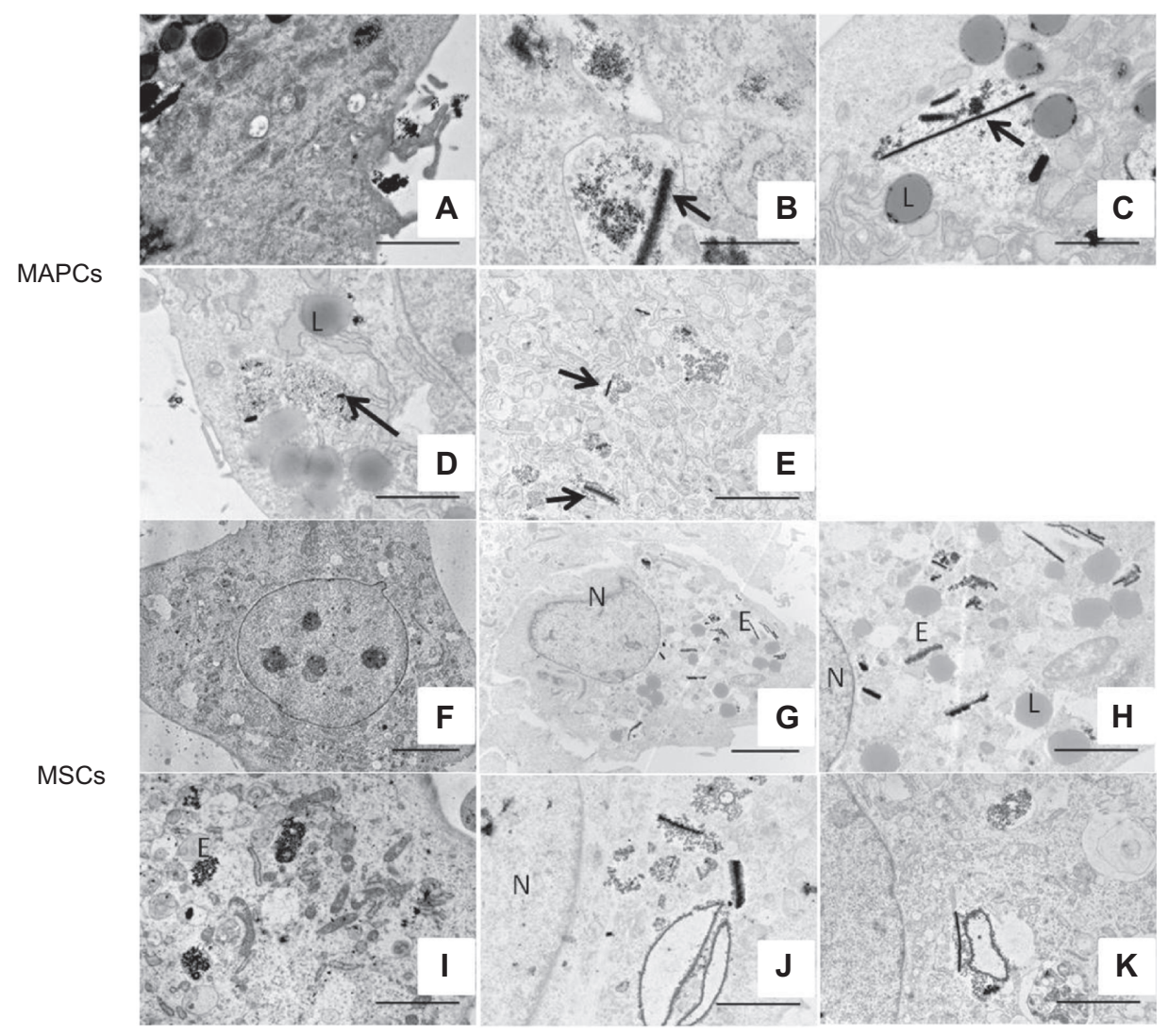

Figure 3 Ultra-structural analysis of MAPCs and MSCs with TEM. (A) Endocytosis was confirmed by the presence of pseudopodia (arrow) and NPs in endosomes. (B and C) MAPCs labeled with Endorem ${ }^{\circledR}$ showed 'rod-like' structures in the endosomes at lower $(50 \mu \mathrm{g} \mathrm{Fe} / \mathrm{mL})$ and at higher $(400 \mu \mathrm{g}$ Fe/mL) iron concentrations in the medium (see arrow in panel B and C). (D) Addition of PLL avoided 'rod-like' structures at lower iron concentrations ( $50 \mu \mathrm{g} \mathrm{Fe/mL} \mathrm{medium),} \mathrm{but} \mathrm{(E)} \mathrm{indicates} \mathrm{presence} \mathrm{of} \mathrm{'rod-like'}$ (arrow) structures at higher concentrations $\left(400 \mu \mathrm{g} \mathrm{Fe} / \mathrm{mL}\right.$ medium). (F) Non-labeled MSCs. (G) MSCs labeled with Endorem ${ }^{\circledR}$ using $50 \mu \mathrm{g}$ Fe/mL medium indicated the presence of rod-like structures, which is further highlighted in $(\mathbf{H})$, the same image as (G) but with a higher magnification. (I) Homogenously distributed NPs were observed in endosomes when PLL was added to Endorem ${ }^{\circledR}(50 \mu \mathrm{g} \mathrm{Fe} / \mathrm{mL}$ medium). (J and $\mathbf{K})$ Rod-like structures were still present in MSCs for higher concentrations of $200 \mu \mathrm{g} \mathrm{Fe} / \mathrm{mL}$ and $400 \mu \mathrm{g} \mathrm{Fe} / \mathrm{mL}$ in the medium, respectively.

Notes: Scale bar: A, C-E, $\mathbf{H}-\mathbf{K}=2 \mu \mathrm{m} ; \mathbf{B}=500 \mathrm{~nm} ; \mathbf{F}-\mathbf{G}=5 \mu \mathrm{m}$.

Abbreviations: E, endosomes; L, lysosomes; MAPCs, multipotent adult progenitor cells; MSCs, mesenchymal stem cells; N, nucleus; NPs, nanoparticles; PLL, poly-L-lysine; TEM, transmission electron microscopy.

thereby forming multiple 'rod-like' structures for all labeling concentrations (50-400 $\mu \mathrm{g} \mathrm{Fe} / \mathrm{mL}$ medium, corresponding to $3.2 \pm 0.2$ to $16.7 \pm 2.7 \mathrm{fg} / \mu^{3}$, Figure $3 \mathrm{~B}$ and $\mathrm{C}$ ). In contrast, homogenous distribution of Endorem ${ }^{\circledR}$ particles in endosomes was observed when PLL $(1.5 \mu \mathrm{g} / \mathrm{mL})$ was added during incubation with low concentrations of Endorem ${ }^{\circledR}$ (at $50 \mu \mathrm{g} \mathrm{Fe} / \mathrm{mL}$ medium, corresponding to $12.8 \pm 1.1 \mathrm{fg} / \mu \mathrm{m}^{3}$, Figure 3D). With increased NP concentrations in the medium, 'rod like' structures also reappeared in the presence of PLL (Figure 3E). Similar observations were made for MSCs when labeled with Endorem ${ }^{\circledR}$ (Figure 3F-K). For comparison with electron microscopy images of pure particles, we refer the reader to Hodenius et $\mathrm{al}^{36}$ for citrate-coated particles, Jung and Jacobs ${ }^{37}$ for Endorem ${ }^{\circledR}$, and to Figure S2 for the MLs.

When MAPCs were incubated with VSOPs, they showed high endocytotic uptake with labeling concentrations of $50 \mu \mathrm{g} \mathrm{Fe} / \mathrm{mL}$ medium (corresponding to $13.1 \pm 4.7 \mathrm{fg} / \mu \mathrm{m}^{3}$ ).
MAPCs with higher incubation concentrations of $200 \mu \mathrm{g} \mathrm{Fe} / \mathrm{mL}$ also showed a dilated endoplasmic reticulum and the presence of vacuoles, which suggests cellular stress (Figure 4A and B), further supporting the results from the MTT assays and reduced cell counts (Figure 2A and E). MSCs showed a steady increase in the uptake of VSOPs (confirmed with ICP-OES, Figure 1), with increased concentrations in the medium up to 200 $\mu \mathrm{g} \mathrm{Fe} / \mathrm{mL}$. Similar to MAPCs, indications of stress were also seen for MSCs at concentrations of at least $200 \mu \mathrm{g}$ $\mathrm{Fe} / \mathrm{mL}$ medium (corresponding to $0.7 \pm 0.7 \mathrm{fg} / \mu^{3}{ }^{3}$, Figure 4D). As labeling with MLs resulted in a reduction of metabolic activity of MAPCs at concentrations as low as $50 \mu \mathrm{g} \mathrm{Fe} / \mathrm{mL}$, we did not further analyze the ultrastructure of MAPCs labeled with MLs. TEM of MSCs showed homogenously distributed NPs in endosomes and showed no indication of stress when labeled with MLs 

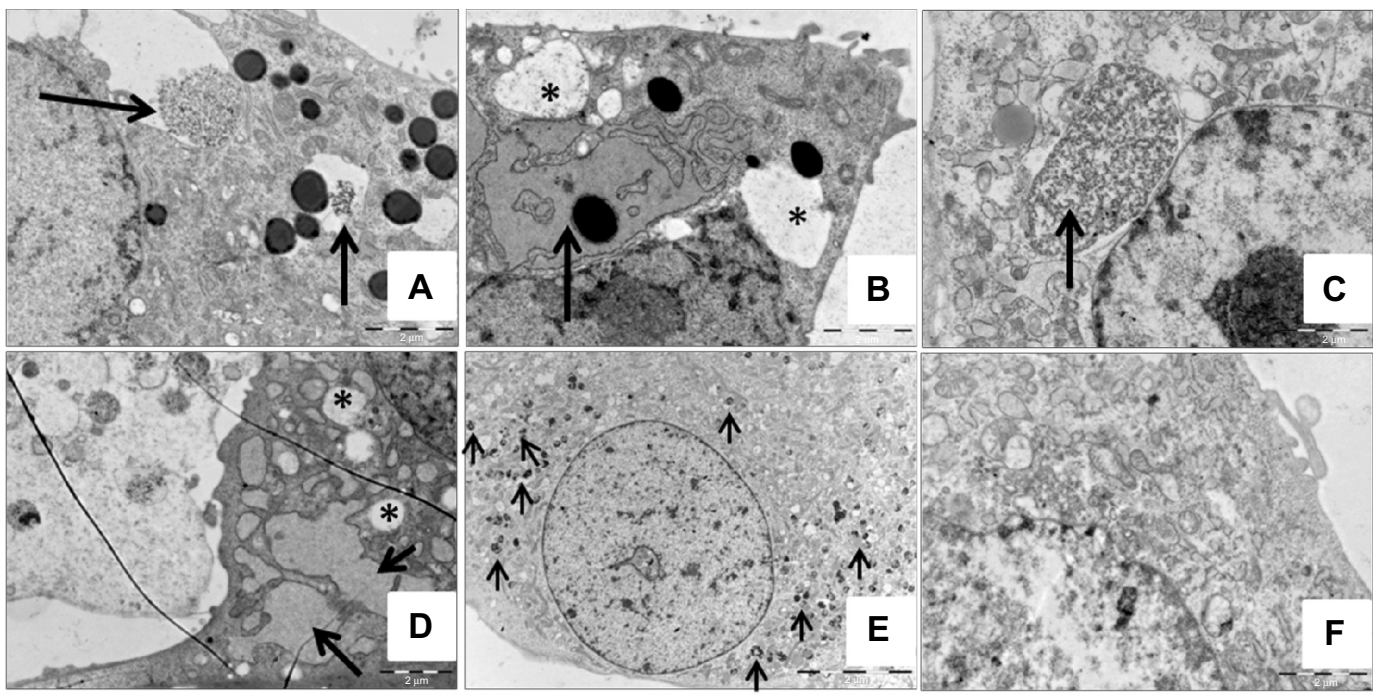

G

Endorem $^{\circledR}$

Endorem ${ }^{\circledast}+$ PLL

VSOPs

MLs
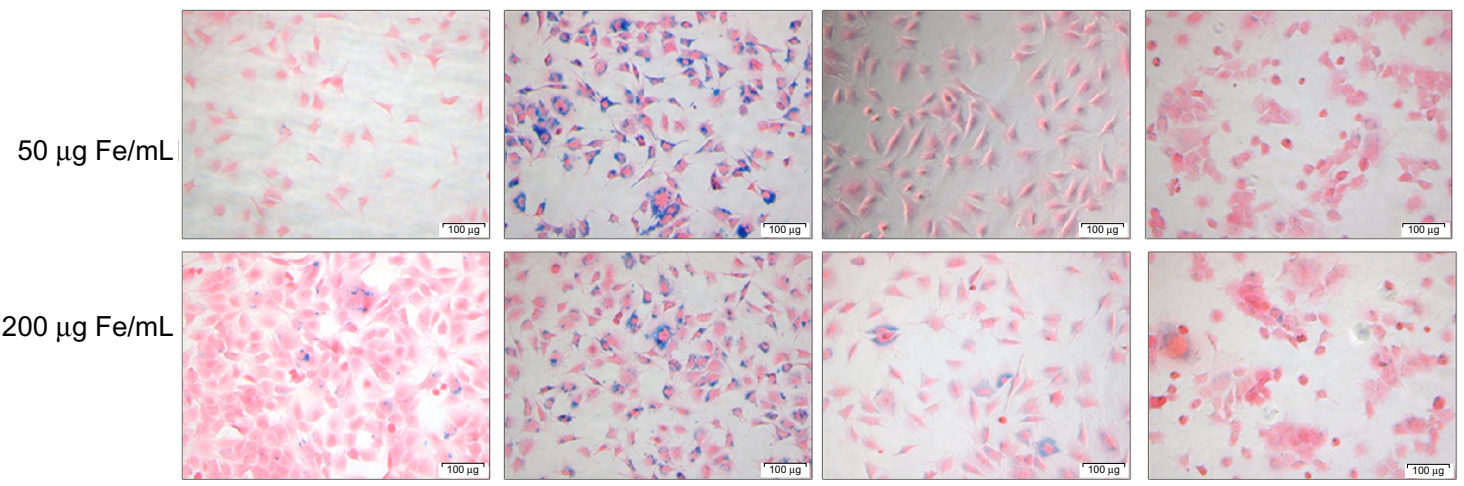

Figure 4 Uptake confirmation of MAPCs and MSCs: (A) VSOPs (50 $\mu \mathrm{g} \mathrm{Fe} / \mathrm{mL}$ medium) incubated with MAPCs showed endocytotic uptake (arrow). (B) For higher iron

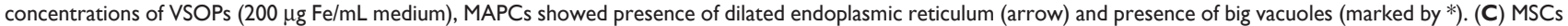
labeled with VSOPs (50 $\mu \mathrm{g} \mathrm{Fe} / \mathrm{mL}$ medium), showed presence of homogeneously distributed NPs in endosomes (black arrow). (D) Adverse effects were confirmed in MSCs labeled with VSOPs (200 $\mu \mathrm{g} \mathrm{Fe} / \mathrm{mL}$ medium) when vacuoles $(*)$ and dilated EPR (arrows) were observed. (E) Homogenous distribution of NPs in endosomes was clearly observed when MSCs labeled with MLs (arrows). (F) Non-labeled MSCs. (G) Iron uptake was also confirmed with Prussian blue staining (in MSCs with all particles).

Notes: Scale bar: $\mathbf{A}-\mathbf{D}, \mathbf{F}=2 \mu \mathrm{m} ; \mathbf{E}=10 \mu \mathrm{m} ; \mathbf{G}=100 \mu \mathrm{m}$.

Abbreviations: EPR, endoplasmic reticulum; MAPCs, multipotent adult progenitor cells; MSCs, mesenchymal stem cells; MLs, magnetoliposomes; NPs, nanoparticles; PLL, poly-L-lysine; VSOPs, very small iron oxide particles.

up to $400 \mu \mathrm{g} \mathrm{Fe} / \mathrm{mL}$ medium (corresponding to $0.8 \pm 0.1$ $\mathrm{fg} / \mu \mathrm{m}^{3}$, Figure $\left.4 \mathrm{E}\right)$.

Label internalization was also confirmed by Prussian blue staining. Figure 4G shows Prussian blue staining of MSCs labeled with different NPs. Maximum staining was observed when MSCs were labeled with Endorem ${ }^{\circledR}+$ PLL (at $50 \mu \mathrm{g} \mathrm{Fe} / \mathrm{mL}$ medium), which correlates with ICP-OES measurements (Figure 1).

Both cell types differed in their apparent toxicity profile and intracellular iron uptake when labeled with the same particles. Smaller cells such as MAPCs were susceptible to lower concentrations in the medium $(50 \mu \mathrm{g} \mathrm{Fe} / \mathrm{mL})$ when labeled with VSOPs and MLs, but also showed significantly higher uptake and intracellular amounts of iron. When based on intracellular concentrations, MAPCs and MSCs were similarly tolerant to the various contrast agents, highlighting the importance of expressing parameters such as toxicity and iron uptake in concentrations rather than amounts.

\section{MRI detectability}

Cells labeled with NPs were visualized due to their effect on the magnetic susceptibility and thereby reduced signal intensity in T2*-weighted MR images. For comparative MRI sensitivity studies, we kept the cell density low and constant (500 cells $/ \mu \mathrm{L}$ ) for phantoms containing labeled MAPCs and MSCs. Figure 5 shows three-dimensional T2*weighted MRI scans and T2 relaxation time measurements post-labeling. Endorem ${ }^{\circledR}$-labeled MAPCs showed a gradual 
A

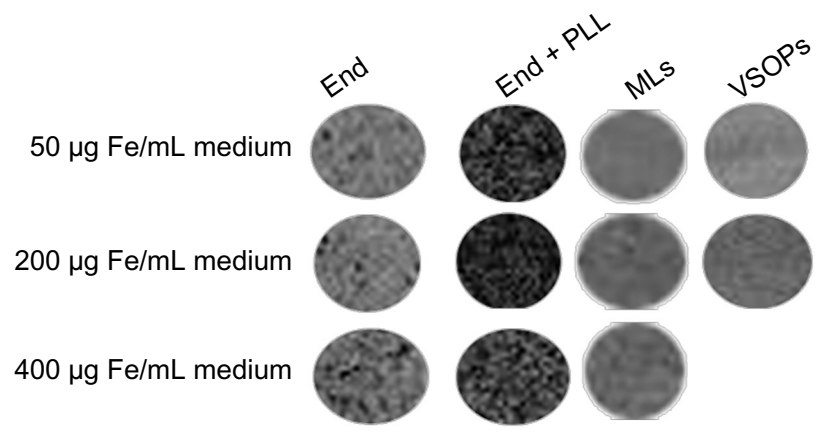

C

$50 \mu \mathrm{g} \mathrm{Fe} / \mathrm{mL}$ medium

$200 \mu \mathrm{g} \mathrm{Fe} / \mathrm{mL}$ medium

$400 \mu \mathrm{g} \mathrm{Fe} / \mathrm{mL}$ medium
MSCs

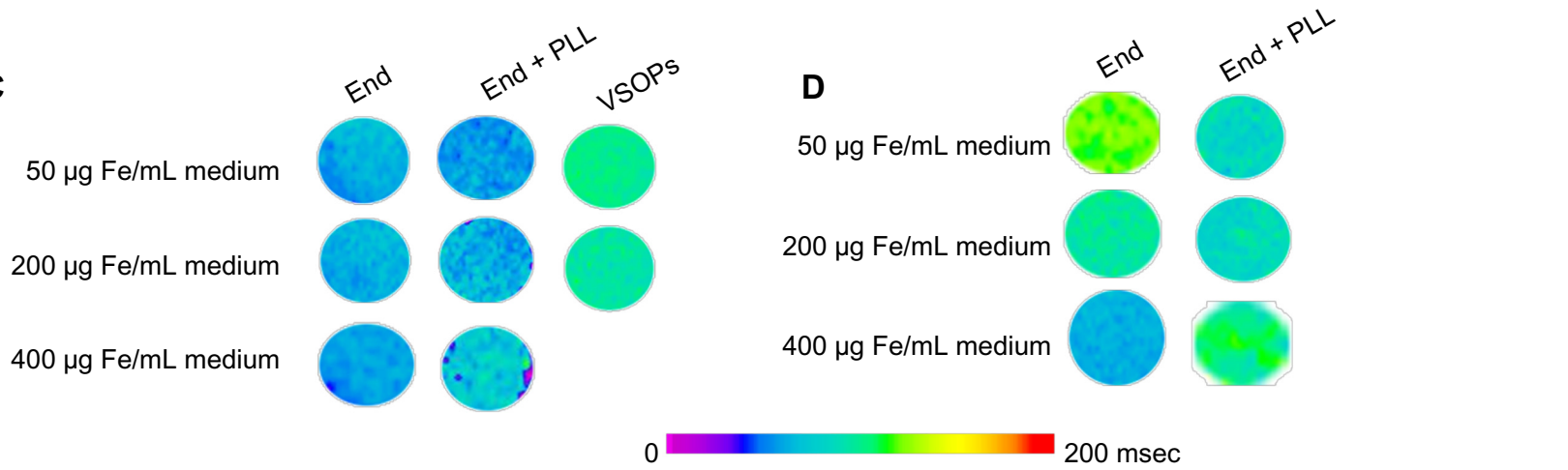

B

\section{MAPCs}

Figure 5 MR detection of labeled MAPCs and MSCs. (A and B) show the presence of hypo-intense spots of labeled MSCs and MAPCs, respectively, in FLASH threedimensional T2*-weighted scans with cell density of 500 cells/ $\mu \mathrm{L}$. (C and D) Quantitative analysis of reduction in T2-relaxation times was determined using MSME MRI experiments. Maximum reduction with respect to T2 relaxation times was seen when MSCs were labeled with Endorem ${ }^{\circledR}+$ PLL.

Abbreviations: End, Endorem ${ }^{\circledast}$; MAPCs, multipotent adult progenitor cells; MRI, magnetic resonance imaging; MSCs, mesenchymal stem cells; MSME, multi-slice-multi-echo; PLL, poly-L-lysine; VSOPs, very small iron oxide particles.

decrease in signal intensity with increased iron concentrations. Clear effects on MRI detectability due to improved labeling efficiency of MSCs were seen with the addition of PLL to Endorem ${ }^{\circledR}$, reducing the signal intensity down to $40 \%$ with respect to non-labeled cells at the lowest concentration of $50 \mu \mathrm{g} \mathrm{Fe} / \mathrm{mL}$ medium (corresponding to $1.1 \pm 0.1 \mathrm{fg} / \mu \mathrm{m}^{3}$, see Figure 5A). These reductions in the signal intensity correlate well with ICP-OES data from Figure 1.

The only tolerable concentration for MAPC labeling with MLs was $20 \mu \mathrm{g} \mathrm{Fe} / \mathrm{mL}$ medium (corresponding to $\left.2.8 \pm 2 \mathrm{fg} / \mu \mathrm{m}^{3}\right)$, which also resulted in detectable cells in agar phantoms. Due to the adverse effects of MLs on MAPC survival, higher ML concentrations were excluded from further comparisons. Unlike MAPCs, MSCs only displayed adverse effects on cell biology when labeled with the highest NP concentration $400 \mu \mathrm{g} \mathrm{Fe} / \mathrm{mL}$ medium (corresponding to $0.8 \pm 0.1$ $\left.\mathrm{fg} / \mu \mathrm{m}^{3}\right)$. Although MAPCs initially showed high VSOP uptake (Figure 1), contrast changes and reductions in T2 values in the respective MR images was significantly lower than with $50 \mu \mathrm{g} \mathrm{Fe} / \mathrm{mL}$ medium Endorem ${ }^{\circledR} \pm \mathrm{PLL}$ ). Figure $5 \mathrm{C}$ and $\mathrm{D}$ shows the color-coded images of $\mathrm{T} 2$ relaxation times for
MSCs and MAPCs labeled with respective NPs. T2 relaxation times decreased with increased iron concentrations for most of the labeling conditions, and showed similar trends as for relative signal intensity changes in three-dimensional $\mathrm{T} 2{ }^{*}$ weighted MRI. The strongest effects were seen for MSCs labeled with Endorem ${ }^{\circledR}+$ PLL.

\section{Label dilution}

The fate of NPs after continued cell proliferation was evaluated with MR three-dimensional T2*-weighted highresolution images and TEM. Figure 6 shows label dilution over time for MAPCs labeled with Endorem ${ }^{\circledR}$ (Figure 6A) and MSCs with Endorem ${ }^{\circledR}+$ PLL (Figure 6B). MAPCs in a suspension of 500 cells $/ \mu \mathrm{L}$ were detectable (as hypointense spots) in MR scans for up to 4 days post-labeling, whereas MSCs, as slowly proliferating cells, were detectable until day 6 post-labeling with Endorem ${ }^{\circledR}+$ PLL.

Figure 6C indicates label dilution over time for $200 \mu \mathrm{g} \mathrm{Fe} / \mathrm{mL}$ medium Endorem ${ }^{\circledR} \pm$ PLL and VSOPs as well as $50 \mu \mathrm{g} \mathrm{Fe} / \mathrm{mL}$ medium of MLs. Endorem ${ }^{\circledR}$ and VSOPs were detectable in endosomes until day 5 post-labeling, whereas 
A

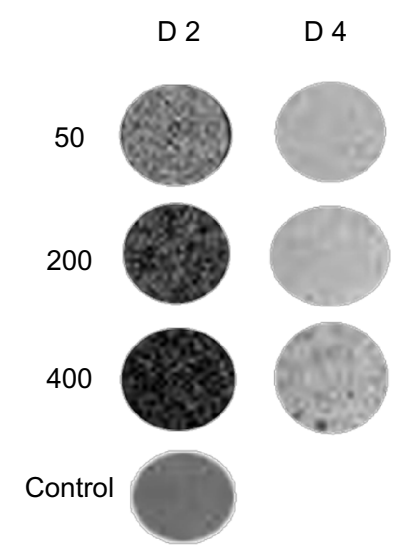

C

Day 2

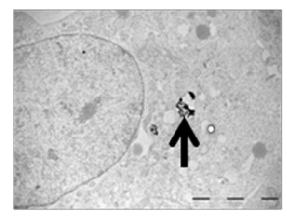

Day 5

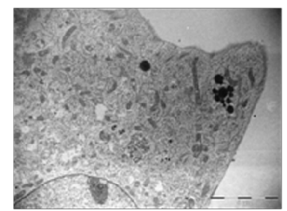

Day 8
Endorem $^{\circledR}+$ PLL
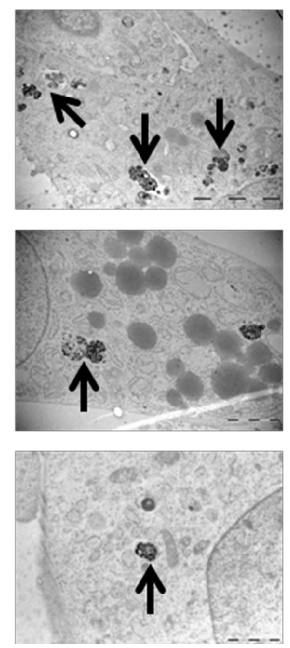

B MAPCs + Endorem ${ }^{\circledast}+$ PLL

50
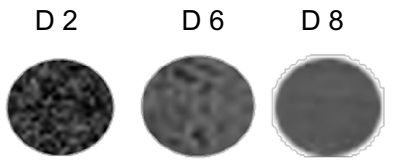

200

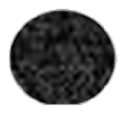

.

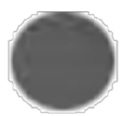

400
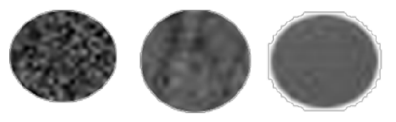

Control

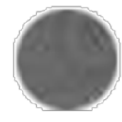

MLs
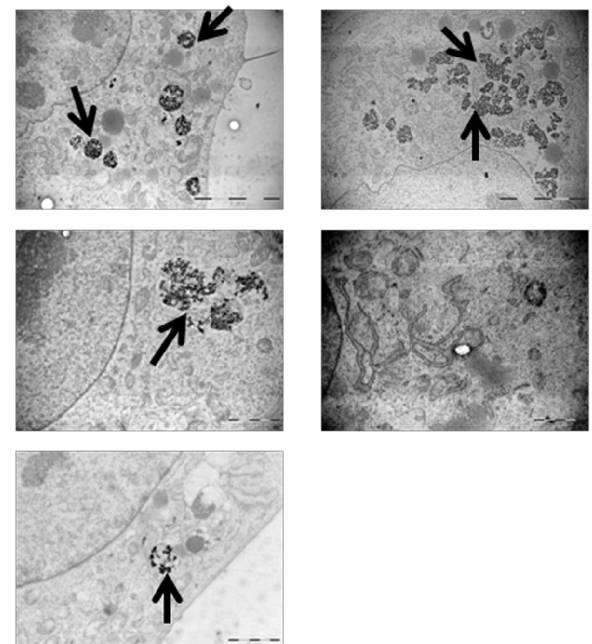

Figure 6 Label dilution in MAPCs and MSCs. Label dilution over time due to cell proliferation was confirmed using high-resolution three-dimensional T2*-weighted scans and TEM. (A) MAPCs labeled with Endorem ${ }^{\circledR}$ with $200 \mu \mathrm{g} \mathrm{Fe} / \mathrm{mL}$ medium (with cell density of 500 cells/ $\mu \mathrm{L}$ ) were detected by MRI until day 4 . (B) MSCs labeled with Endorem $^{\circledast}+\mathrm{PLL}$ at $50 \mu \mathrm{g} \mathrm{Fe} / \mathrm{mL}$ medium (with cell density of 500 cells/ $\mu \mathrm{L}$ ) were detectable for 6 days post-labeling. (C) Electron microscopy analysis was done for all MSC-labeling conditions. It was observed that, although MLs were taken up in significantly lower quantities than Endorem ${ }^{\circledR}+$ PLL, they degraded slowly by the intracellular environment and were present in the endosomes until day 8 post-labeling.

Notes: Scale bar: all day 2 images $=5 \mu \mathrm{m}$; all day 5, 8 images $=2 \mu \mathrm{m}$. Arrows indicate presence of NPs in endosomes for different labeling conditions.

Abbreviations: MAPCs, multipotent adult progenitor cells; MLs, magnetoliposomes; MRI, magnetic resonance imaging; MSCs, mesenchymal stem cells; NPs, nanoparticles; PLL, poly-L-lysine; TEM, transmission electron microscopy; VSOPs, very small iron oxide particles.

MLs and Endorem ${ }^{\circledR}+$ PLL were observed in endosomes even after 8 days post-labeling.

\section{Discussion}

Cell labeling with iron oxide-based NPs has become a common strategy for subsequent in vitro and in vivo cell visualization using microscopic and non-invasive imaging methods. Due to this increased number of applications in biological systems, assessment of the sensitivity, toxicity, and adverse effects of NPs on cell biology has become a topic of interest. An extensive number of studies have evaluated the effect of NP labeling on cell homeostasis; some of which have pointed to negative effects of particle incorporation on cell viability, ${ }^{38}$ actin cytoskeleton structure, ${ }^{39}$ differentiation potential, ${ }^{40,41}$ receptor expression, ${ }^{42,43}$ migratory capabilities, ${ }^{44,45}$ and reactive oxygen species (ROS) generation, ${ }^{46}$ suggesting the need for in vitro evaluation before their in vivo application. The number of studies focusing on cell-related rather than NPrelated parameters is limited.

In this study, we used three different types of iron oxidebased contrast agents (with respect to their size and coating) for labeling of two cell lines (MSCs and MAPCs) differing in cell size and doubling time in order to study the effect of cell-related factors on NP uptake and fate, using TEM for ultrastructural analysis. Though both cell types have a similar origin, they possess different properties. MAPCs represent 
a rare cell population that can differentiate to endothelium and endodermal lineages. Extensive research has been conducted in isolating MAPCs from mice, rats, and humans (commercially available clinical grade stem cell product MultiStem $\left.^{\circledR}\right) .{ }^{11,47}$

\section{Cell volume and NP uptake and toxicity}

In most studies, the cellular content of iron oxide-based NPs is expressed as an amount per cell. Considering the vast variability in cell size in stem and progenitor cells, the same amount of NPs would result in a similarly large variability of intracellular NP concentrations. For example, while the pheochromocytoma cell line PC12 is relatively small (diameter of $<10 \mu \mathrm{m}$ ) and takes up less iron oxide-based NPs than the much larger neural progenitor cell line C17.2, the ultimate intracellular iron concentration was comparable. ${ }^{48}$ Similarly, MSCs studied here have a ten times larger volume than MAPCs. When MSCs and MAPCs were labeled with VSOPs and MLs, significant variations were observed in the intracellular iron content and toxicity. When compared with MSCs, smaller MAPCs endocytosed smaller particles (VSOPs: $18.2 \pm 3.9 \mathrm{pg} / \mathrm{cell}$ and MLs: $10.40 \pm 0.9 \mathrm{pg} / \mathrm{cell}$, at labeling concentrations of $50 \mu \mathrm{g} \mathrm{Fe} / \mathrm{mL}$ medium) in higher quantities compared with Endorem ${ }^{\circledR}(4.6 \pm 1.2 \mathrm{pg} /$ cell). The number of particles coming into contact with the cell membrane is higher with decreasing diameters of the particles. This effect is more pronounced for the uptake by smaller cells (MAPCs: 9-14 $\mu \mathrm{m}$ ) compared with larger cells (MSCs: $30-50 \mu \mathrm{m}$ ). In addition to their volume occupancy (Table 2) due to the smaller diameter, other possible reasons for their toxicity could also be the lower stability of VSOPs. ${ }^{48,49}$

In addition to differences in uptake mechanisms, the iron storage capacity of cells might also be cell dependent. Based on the calculated relative volume occupied by NPs with respect to the total volume of available cytosol (Table 2), we hypothesize that every cell has some iron storage capacity per cell volume, and once exceeded, may cause toxicity due to iron overload..$^{50}$ As our observations indicate a relationship between cytosol volume, intracellular iron concentration, and toxicity, it would be beneficial for the comparison of different cell-labeling studies to express NP uptake in intracellular concentrations (iron mass/volume of cytosol) rather than amounts (mass per single cell). As indicated in Figure 1, similar amounts of iron in cells translate into manyfold differences of intracellular concentrations and possibly explain adverse effects of NPs on cell biology. Compared with MAPCs, the larger MSCs were more tolerant to higher NP concentrations in the medium, which was evident from proliferation, viability, and TEM (absence of vacuoles and dilated endoplasmic reticulum). Although no cell differentiation experiments were performed in this study, previous work on the same cell lines has indicated similar trends. ${ }^{33}$

\section{Formation of aggregates}

Based on the cell viability tests, MR contrast generation, and label dilution over time, optimal, non-toxic NP concentrations in the medium were selected to be $200 \mu \mathrm{g} \mathrm{Fe} / \mathrm{mL}$ of Endorem ${ }^{\circledR}$ for MAPCs and $50 \mu \mathrm{g} \mathrm{Fe} / \mathrm{mL}$ medium (corresponding to $1.1 \pm 0.1 \mathrm{fg} / \mu^{3}$ ) Endorem ${ }^{\circledR}+$ PLL for MSCs. From iron quantification measurements and T2 maps, it was observed that labeling of MAPCs with Endorem ${ }^{\circledR}$ was more effective than Endorem ${ }^{\circledR}$ in the presence of a transfection agent, confirming previous observations. ${ }^{33}$ In contrast, conjugation of $388 \mathrm{kDa}$ PLL $(1.5 \mu \mathrm{g} / \mathrm{mL})$ showed a significant increase in iron uptake by MSCs without affecting their viability. TEM images indicated that upon Endorem ${ }^{\circledR}$ labeling, 'rod-like' aggregates were observed. These observations are in line with a detailed study on interactions between lipofectamine and Endorem ${ }^{\circledR}$ complexes, suggesting that such aggregates are formed in the presence of serum and that the degree of aggregation depends on the ratio of the transfection agent to NPs. ${ }^{51}$ This can be explained by inadequate surface covering of NPs with PLL moieties, leading to heterogeneity in local surface charges, thus increasing affinity for charged serum proteins to the complex surface, leading to protein corona. ${ }^{52}$ It has also been shown in the literature that dextran-coated cores are easily metabolized when present in endosomes at a lower $\mathrm{pH} .{ }^{53}$ The 'rod-like' structures have not been reported before, except for labeling experiments where cells were exposed to external magnetic fields. ${ }^{54}$ Those aggregates can potentially be beneficial in applications where pre-labeled cells are transplanted for longitudinal studies. If stable over time, such aggregates will not be further diluted with proliferation, hereby enabling longer detectability in vivo. Although we did not see any detrimental effects of these aggregates on population doubling population in follow-up experiments, further investigations related to the generation of ROS and differentiation potential would be needed.

\section{Label dilution over time}

Longitudinal assessment of contrast by MRI is limited due to the label dilution by proliferating cells. In this study, we determined the fate of NPs for 1 week post-labeling with the help of MRI and high-resolution TEM. PDT for MSCs was approximately 25 hours and for MAPCs around 12 hours. Endorem $^{\circledR}$ was only detectable for 4 days (approximately 
eight divisions) in the rapidly proliferating MAPCs. Where MSCs were labeled with Endorem ${ }^{\circledR}$, hypointense contrast in MRI (cell density of 500 cells/ $\mu \mathrm{L}$ ) was seen until day 6 post-labeling (approximately five cell divisions). However, it was obvious from TEM images that these particles were present in the endosomes until day 8 post-labeling. For in vivo applications, longer observation periods are possible due to the slower proliferation under in vivo conditions. The minor discrepancy in PDT and MRI detectability as seen between MAPC and MSC can also be explained by biodegradation of NPs and subsequent recycling of iron by the cells or potential exocytosis if cells are monitored over long periods.

Ultrastructural analysis of MSCs labeled with $50 \mu \mathrm{g} \mathrm{Fe} / \mathrm{mL}$ medium Endorem ${ }^{\circledR}+$ PLL and MLs showed retention of particles in the endosomal compartment for 1 week postlabeling. Intracellular iron concentrations immediately after MSC labeling were found to be much lower for MLs $\left(0.1 \mathrm{fg} / \mu \mathrm{m}^{3}\right)$ than for Endorem ${ }^{\circledR}+$ PLL $\left(1.2 \mathrm{fg} / \mu \mathrm{m}^{3}\right)$ at $50 \mu \mathrm{g} \mathrm{Fe} / \mathrm{mL}$ medium. The retention of NPs in the cells for more than 1 week for both NPs indicates a slower degradation of MLs compared with Endorem ${ }^{\circledR}+$ PLL, as also previously found for other cell types. ${ }^{48}$ This observation indicates that the fate of the intracellular particles is also decided by the coating of NPs and highlights the need for ultrastuctural analyses. Although cationic MLs can have adverse effects on cell physiology if present at high intracellular concentrations, as for the smaller MAPCs, they have the advantage of providing information in longitudinal studies if concentrations are carefully adjusted. ${ }^{48}$

\section{Conclusion}

Differences in nanoparticle interactions with different cell lines are not only influenced by the size, coating, surface charge, and other properties of the contrast agent but also depend on cellular parameters such as size or doubling times. This not only results in differences in nanoparticle uptake and contrast generation but also affects the assessment of potentially toxic responses. The cell size dependence of celllabeling strategies also stresses the importance of expressing the uptake of contrast agents in concentrations (iron mass/ volume of cytosol) rather than in amounts to allow meaningful inter-study comparisons. Our results also confirm that it is necessary to validate cell-contrast agent interactions for each combination.

\section{Acknowledgments}

The authors are grateful to Guerbet, Roissy, France, for the generous gift of Endorem ${ }^{\circledR}$. The technical assistance of Marc
Jans, Manja Muitjens, and Pieter Berckmans is gratefully acknowledged. We would like to thank Jesse Trekker for the assistance with ICP-OES measurements. This work was financially supported by the European commission project EC-FP7-NMP-2008-Large 'ViBRANT' (228933), the Flemish Government for the SBO-IWT-80017 'iMAGiNe' and the SBO-IWT-060838 'BRAINSTIM', and by the KU Leuven Program Financing 'IMIR'. AKA is grateful for receiving financial support for a $\mathrm{PhD}$ fellowship (DBOF) from the KU Leuven.

\section{Disclosure}

CMV is a consultant for ReGenesys, BVBA. All other authors declare no conflicts of interest in this work.

\section{References}

1. Guo QS, Zhu MY, Wang L, et al. Combined transfection of the three transcriptional factors, PDX-1, NeuroD1, and MafA, causes differentiation of bone marrow mesenchymal stem cells into insulin-producing cells. Exp Diabetes Res. 2012;2012:672013.

2. Jacobs SA, Pinxteren J, Roobrouck VD, et al. Human multipotent adult progenitor cells are non-immunogenic and exert potent immunomodulatory effects on alloreactive T cell responses. Cell Transplant. Epub October 1, 2012.

3. Mora-Lee S, Sirerol-Piquer MS, Gutiérrez-Pérez M, et al. Therapeutic effects of hMAPC and hMSC transplantation after stroke in mice. PLoS One. 2012;7(8):e43683.

4. Scheibe F, Ladhoff J, Huck J, et al. Immune effects of mesenchymal stromal cells in experimental stroke. J Cereb Blood Flow Metab. 2012;32(8):1578-1588.

5. Walker PA, Bedi SS, Shah SK, et al. Intravenous multipotent adult progenitor cell therapy after traumatic brain injury: modulation of the resident microglia population. J Neuroinflammation. 2012;9:228.

6. Barry FP, Murphy JM. Mesenchymal stem cells: clinical applications and biological characterization. Int J Biochem Cell Biol. 2004;36(4): 568-584.

7. Pittenger MF, Mackay AM, Beck SC, et al. Multilineage potential of adult human mesenchymal stem cells. Science. 1999;284(5411):143-147.

8. Toma C, Pittenger MF, Cahill KS, Byrne BJ, Kessler PD. Human mesenchymal stem cells differentiate to a cardiomyocyte phenotype in the adult murine heart. Circulation. 2002;105(1):93-98.

9. Jiang XX, Zhang Y, Liu B, et al. Human mesenchymal stem cells inhibit differentiation and function of monocyte-derived dendritic cells. Blood. 2005;105(10):4120-4126.

10. Wang M, Yang Y, Yang D, et al. The immunomodulatory activity of human umbilical cord blood-derived mesenchymal stem cells in vitro. Immunology. 2009;126(2):220-232.

11. Jiang Y, Jahagirdar BN, Reinhardt RL, et al. Pluripotency of mesenchymal stem cells derived from adult marrow. Nature. 2002;418(6893):41-49.

12. Sohni A, Verfaillie CM. Multipotent adult progenitor cells. Best Pract Res Clin Haematol. 2011;24(1):3-11.

13. Binas B, Verfaillie CM. Concise review: bone marrow meets blastocyst: lessons from an unlikely encounter. Stem Cells. 2012;31(4):620-626.

14. Lo Nigro A, Geraerts M, Notelaers T, et al. MAPC culture conditions support the derivation of cells with nascent hypoblast features from bone marrow and blastocysts. J Mol Cell Biol. 2012;4(6):423-426.

15. Cromer Berman SM, Walczak P, Bulte JW. Tracking stem cells using magnetic nanoparticles. Wiley Interdiscip Rev Nanomed Nanobiotechnol. 2011;3(4):343-355.

16. Himmelreich $U$, Hoehn M. Stem cell labeling for magnetic resonance imaging. Minim Invasive Ther Allied Technol. 2008;17(2):132-142. 
17. Bulte JW, Arbab AS, Douglas T, Frank JA. Preparation of magnetically labeled cells for cell tracking by magnetic resonance imaging. Methods Enzymol. 2004;386:275-299.

18. Hoehn M, Küstermann E, Blunk J, et al. Monitoring of implanted stem cell migration in vivo: a highly resolved in vivo magnetic resonance imaging investigation of experimental stroke in rat. Proc Natl Acad Sci U S A. 2002;99(25):16267-16272.

19. Hoshino K, Ly HQ, Frangioni JV, Hajjar RJ. In vivo tracking in cardiac stem cell-based therapy. Prog Cardiovasc Dis. 2007;49(6):414-420.

20. Zhang SJ, Wu JC. Comparison of imaging techniques for tracking cardiac stem cell therapy. J Nucl Med. 2007;48(12):1916-1919.

21. Adonai N, Nguyen KN, Walsh J, et al. Ex vivo cell labeling with 64Cu-pyruvaldehyde-bis(N4-methylthiosemicarbazone) for imaging cell trafficking in mice with positron-emission tomography. Proc Natl Acad Sci U S A. 2002;99(5):3030-3035.

22. Connor DM, Benveniste H, Dilmanian FA, Kritzer MF, Miller LM, Zhong Z. Computed tomography of amyloid plaques in a mouse model of Alzheimer's disease using diffraction enhanced imaging. Neuroimage. 2009;46(4):908-914.

23. Chaudhari AJ, Darvas F, Bading JR, et al. Hyperspectral and multispectral bioluminescence optical tomography for small animal imaging. Phys Med Biol. 2005;50(23):5421-5441.

24. Himmelreich U, Dresselaers T. Cell labeling and tracking for experimental models using magnetic resonance imaging. Methods. 2009;48(2):112-124.

25. Neoh KG, Kang ET. Surface modification of magnetic nanoparticles for stem cell labeling. Soft Matter. 2012;8(7):2057-2069.

26. Küstermann E, Himmelreich U, Kandal K, et al. Efficient stem cell labeling for MRI studies. Contrast Media Mol Imaging. 2008;3(1):27-37.

27. Thorek DL, Tsourkas A. Size, charge and concentration dependent uptake of iron oxide particles by non-phagocytic cells. Biomaterials. 2008;29(26):3583-3590.

28. Breyer A, Estharabadi N, Oki M, et al. Multipotent adult progenitor cell isolation and culture procedures. Exp Hematol. 2006;34(11): 1596-1601.

29. Subramanian K, Geraerts M, Pauwelyn KA, et al. Isolation procedure and characterization of multipotent adult progenitor cells from rat bone marrow. Methods Mol Biol. 2010;636:55-78.

30. Peister A, Mellad JA, Larson BL, Hall BM, Gibson LF, Prockop DJ. Adult stem cells from bone marrow (MSCs) isolated from different strains of inbred mice vary in surface epitopes, rates of proliferation, and differentiation potential. Blood. 2004;103(5):1662-1668.

31. De Cuyper M, Joniau M. Magnetoliposomes. Formation and structural characterization. Eur Biophys J. 1988;15(5):311-319.

32. Soenen SJ, Vercauteren D, Braeckmans K, Noppe W, De Smedt S, De Cuyper M. Stable long-term intracellular labelling with fluorescently tagged cationic magnetoliposomes. Chembiochem. 2009;10(2): 257-267.

33. Crabbe A, Vandeputte C, Dresselaers T, et al. Effects of MRI contrast agents on the stem cell phenotype. Cell Transplant. 2010;19(8): 919-936.

34. Mosmann T. Rapid colorimetric assay for cellular growth and survival: application to proliferation and cytotoxicity assays. J Immunol Methods. 1983;65(1-2):55-63.

35. Struys T, Ketkar-Atre A, Gervois P, et al. Magnetic resonance imaging of human dental pulp stem cells in vitro and in vivo. Cell Transplant. Epub October 8, 2013.

36. Hodenius MA, Niendorf T, Krombach GA, et al. Synthesis, physicochemical characterization and MR relaxometry of aqueous ferrofluids. J Nanosci Nanotechnol. 2008;8(5):2399-2409.
37. Jung CW, Jacobs P. Physical and chemical properties of superparamagnetic iron oxide MR contrast agents: ferumoxides, ferumoxtran, ferumoxsil. Magn Reson Imaging. 1995;13(5):661-674.

38. Daldrup-Link HE, Meier R, Rudelius M, et al. In vivo tracking of genetically engineered, anti-HER2/neu directed natural killer cells to HER2/ neu positive mammary tumors with magnetic resonance imaging. Eur Radiol. 2005;15(1):4-13.

39. Soenen SJ, Nuytten N, De Meyer SF, De Smedt SC, De Cuyper M. High intracellular iron oxide nanoparticle concentrations affect cellular cytoskeleton and focal adhesion kinase-mediated signaling. Small. 2010;6(7):832-842.

40. Kostura L, Kraitchman DL, Mackay AM, Pittenger MF, Bulte JW. Feridex labeling of mesenchymal stem cells inhibits chondrogenesis but not adipogenesis or osteogenesis. NMR Biomed. 2004;17(7):513-517.

41. Pisanic TR 2nd, Blackwell JD, Shubayev VI, Fiñones RR, Jin S. Nanotoxicity of iron oxide nanoparticle internalization in growing neurons. Biomaterials. 2007;28(16):2572-2581.

42. Schäfer R, Kehlbach R, Wiskirchen J, et al. Transferrin receptor upregulation: in vitro labeling of rat mesenchymal stem cells with superparamagnetic iron oxide. Radiology. 2007;244(2):514-523.

43. Pawelczyk E, Arbab AS, Pandit S, Hu E, Frank JA. Expression of transferrin receptor and ferritin following ferumoxides-protamine sulfate labeling of cells: implications for cellular magnetic resonance imaging. NMR Biomed. 2006;19(5):581-592.

44. Schäfer R, Kehlbach R, Müller M, et al. Labeling of human mesenchymal stromal cells with superparamagnetic iron oxide leads to a decrease in migration capacity and colony formation ability. Cytotherapy. 2009;11(1):68-78.

45. Nohroudi K, Arnhold S, Berhorn T, Addicks K, Hoehn M, Himmelreich U. In vivo MRI stem cell tracking requires balancing of detection limit and cell viability. Cell Transplant. 2010;19(4):431-441.

46. Stroh A, Zimmer C, Gutzeit C, et al. Iron oxide particles for molecular magnetic resonance imaging cause transient oxidative stress in rat macrophages. Free Radic Biol Med. 2004;36(8):976-984.

47. Ulloa-Montoya F, Kidder BL, Pauwelyn KA, et al. Comparative transcriptome analysis of embryonic and adult stem cells with extended and limited differentiation capacity. Genome Biol. 2007;8(8):R163.

48. Soenen SJ, Himmelreich U, Nuytten N, Pisanic TR 2nd, Ferrari A, De Cuyper M. Intracellular nanoparticle coating stability determines nanoparticle diagnostics efficacy and cell functionality. Small. 2010;6(19):2136-2145.

49. Soenen SJ, Himmelreich U, Nuytten N, De Cuyper M. Cytotoxic effects of iron oxide nanoparticles and implications for safety in cell labelling. Biomaterials. 2011;32(1):195-205.

50. Cohen B, Dafni H, Meir G, Harmelin A, Neeman M. Ferritin as an endogenous MRI reporter for noninvasive imaging of gene expression in C6 glioma tumors. Neoplasia. 2005;7(2):109-117.

51. Soenen SJ, De Smedt SC, Braeckmans K. Limitations and caveats of magnetic cell labeling using transfection agent complexed iron oxide nanoparticles. Contrast Media Mol Imaging. 2012;7(2):140-152.

52. Rocker C, Pötzl M, Zhang F, Parak WJ, Nienhaus GU. A quantitative fluorescence study of protein monolayer formation on colloidal nanoparticles. Nat Nanotechnol. 2009;4(9):577-580.

53. Soenen SJ, De Cuyper M. Assessing cytotoxicity of (iron oxide-based) nanoparticles: an overview of different methods exemplified with cationic magnetoliposomes. Contrast Media Mol Imaging. 2009;4(5):207-219.

54. Fayol D, Luciani N, Lartigue L, Gazeau F, Wilhelm C. Managing magnetic nanoparticle aggregation and cellular uptake: a precondition for efficient stem-cell differentiation and MRI tracking. Adv Healthc Mater. 2013;2(2):313-325. 


\section{Supplementary figures}

MAPCs total cell count post MLs labeling

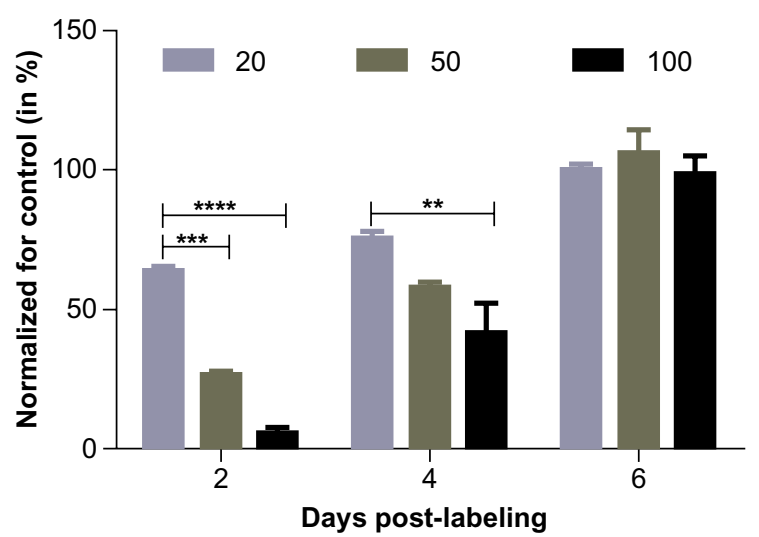

MTT post MLs labeling

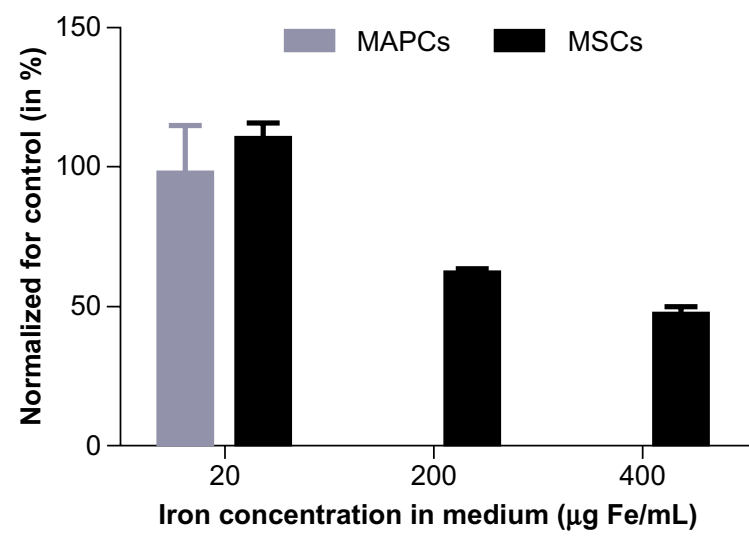

Figure SI Adverse effects on MAPCs and MSCs after labeling with MLs. When MAPCs were labeled with MLs at different concentrations in the medium (20-50-I00 $\mu g$ Fe/mL), toxic effects were observed from $50 \mu \mathrm{g} \mathrm{Fe} / \mathrm{mL}$ medium. On day 2 after labeling, a significant decrease in the total cell count relative to unlabeled control cells was observed, as shown in the left graph. Labeled cells were re-seeded and counted on day 4 and day 6 after labeling with MLs. The total cell counts increased steadily over a period of 6 days, even for the higher concentration $100 \mu \mathrm{g} \mathrm{Fe} / \mathrm{mL}$ medium. The MTT assay was performed on day 2 in 20, 50, 200, and 400 $\mu \mathrm{g} \mathrm{Fe} / \mathrm{mL}$ medium (right graph and Figure 2E), indicating a sharp decrease in the metabolic activity compared with unlabeled control cells. The intracellular iron concentration in the $20 \mu \mathrm{g} \mathrm{Fe} / \mathrm{mL}^{\mathrm{medium}}$ was $2.8 \pm 2 \mathrm{fg} / \mu \mathrm{m}^{3}$ and at $50 \mu \mathrm{g} \mathrm{Fe} / \mathrm{mL}$ medium was $7.4 \pm 0.9 \mathrm{fg} / \mu \mathrm{m}^{3}$, respectively. In case of MSCs, the iron concentration at $50 \mu \mathrm{g} \mathrm{Fe} / \mathrm{mL}$ medium was $0.1 \pm 0.2 \mathrm{fg} / \mu \mathrm{m}^{3}$ ( $\mathrm{Table} 2$ ), which is insignificant compared with MAPCs and caused no toxic effect on the metabolic activity and cell survival of MSCs until $400 \mu \mathrm{g} \mathrm{Fe} / \mathrm{mL}^{\mathrm{medium}}$ (corresponding to $0.8 \pm 0.1 \mathrm{fg} / \mu \mathrm{m}^{3}$ ). Notes: $* * P<0.01$; $* * * P<0.001 ; * * * * P<0.0001$.

Abbreviations: MAPCs, multipotent adult progenitor cells; MLs, magnetoliposomes; MSCs, mesenchymal stem cells; MTT, 3-(4,5-Dimethylthiazol-2-yl)-2,5-diphenyltetrazolium bromide.

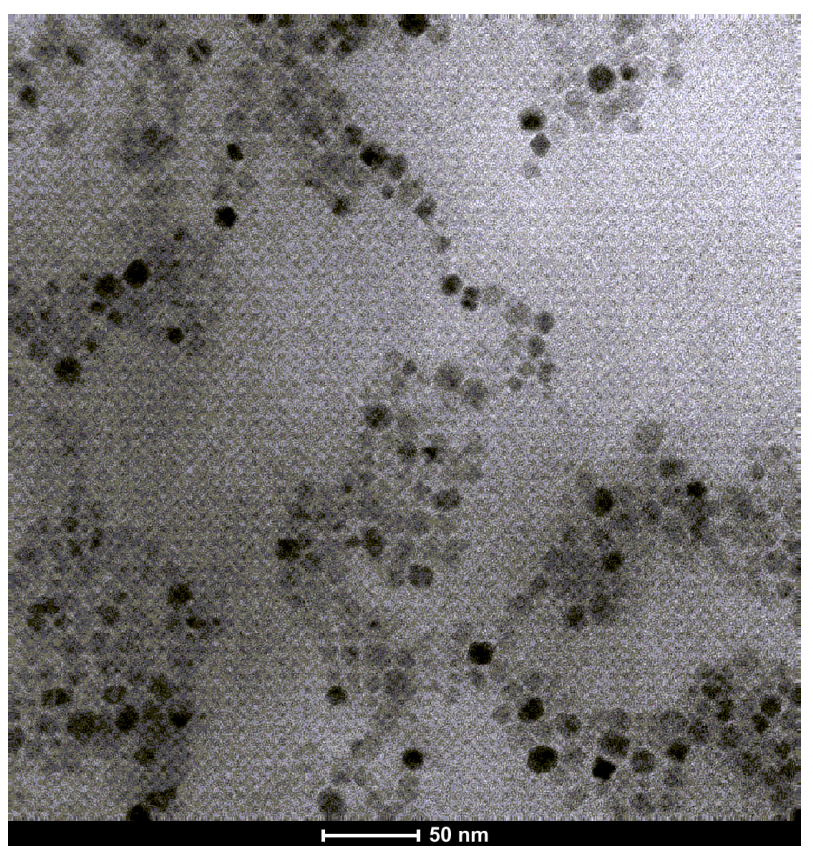

Figure S2 Transmission electron microscopy of magnetoliposomes used for cell labeling.

International Journal of Nanomedicine

\section{Publish your work in this journal}

The International Journal of Nanomedicine is an international, peerreviewed journal focusing on the application of nanotechnology in diagnostics, therapeutics, and drug delivery systems throughou the biomedical field. This journal is indexed on PubMed Central, MedLine, CAS, SciSearch ${ }^{\circledR}$, Current Contents ${ }^{\circledR} /$ Clinical Medicine,

\section{Dovepress}

Journal Citation Reports/Science Edition, EMBase, Scopus and the Elsevier Bibliographic databases. The manuscript management system is completely online and includes a very quick and fair peer-review system, which is all easy to use. Visit http://www.dovepress.com/ testimonials.php to read real quotes from published authors.

\footnotetext{
Submit your manuscript here: http://www.dovepress.com/international-journal-of-nanomedicine-journal
} 